\title{
The Importance of the Secret Ballot in Law Faculty Personnel Decisions: Promoting Candor and Collegiality in the Academy
}

\author{
Ira P. Robbins*
}

\begin{abstract}
* Barnard T. Welsh Scholar and Professor of Law and Justice, American University, Washington College of Law; A.B., University of Pennsylvania; J.D. Harvard Law School. The author is grateful to Anuja Athani, Adrienne Belyea, Sima Bhakta, Lauren Bianchini, Melissa Duvall, and Melissa Troiano for their excellent research assistance, to his colleague Jonathan Baker for reading and commenting on an earlier draft, and to the many law school deans, associate deans, professors, and others who responded to his questionnaires and telephone inquiries.
\end{abstract}




\begin{abstract}
Law school faculty personnel decisions are often controversial. Debates may be heated, votes may be close, and ill will may be incurred. One way to avoid this enmity and to promote or maintain a collegial atmosphere is to vote by secret ballot on hiring, retention, promotion, and tenure questions. The use of secret ballots, however, allows for the possibility of voting for the wrong reasons (e.g., bias, discrimination). But open voting allows for the same possibility (e.g., political correctness, fear of reprisals).

This Article discusses the evolution and significance of the secret ballot and considers the arguments for and against their use on law school faculties. It also presents the results of an original survey (with a 97\% response rate) on the use of secret ballots in faculty personnel decisions at all law schools in the United States. Comments from the survey and conversations and email exchanges between the author and faculty and administrators across the country reveal a subtext that involves, among other things, candor, openness, fairness, and sensitivity, on the one hand, as well as politics, frustration, anger, power, dominance, and control, on the other hand.
\end{abstract}

The Article concludes that, with secret ballots-or, at the very least, with an open and honest debate about whether to conduct secret ballots-may come not only candor, but also greater harmony and collegiality. 


\section{Table of Contents}

Preface

Introduction

I. Background
A. Evolution of the Secret Ballot as a Key Ingredient to Democracy
B. Academic Freedom: Shielding Professors from Unfair Influence

II. Benefits of the Secret Ballot System in Faculty Personnel Decisions
A. The Secret Ballot Encourages Faculty Candor and Eliminates the Chilling Effect
1. An Open Voting System Creates a Chilling Effect on Faculty Candor
2. Repercussions of the Chilling Effect
3. Secret Ballot Critiques and Responses
B. The Secret Ballot Decreases Disharmony Among the Faculty

III. Law Schools' Use of Secret Ballots
A. A Range of Views
B. The Numbers
C. Discussion

Conclusion

Appendix A: Numerical Summary

Appendix B: Use of Secret Ballots in Law School Faculty Personnel Decisions: School by School Tabulation

Appendix C: Comments and Other Uses 


\title{
The Importance of the Secret Ballot in Law Faculty Personnel Decisions: Promoting Candor and Collegiality in the Academy
}

\author{
"Article 21 of the Universal Declaration [of Human Rights] provides for \\ 'periodic and genuine elections . . by universal and equal suffrage and . . by \\ secret vote' as the only process by which democracy can be attained."
}

\section{Preface}

This Article began as an exercise in self-education. At a faculty meeting in the recent past, my colleagues at American University, Washington College of Law, were preparing to vote on a slate of candidates that had been recommended to the faculty by our appointments committee. Because the discussion on some matters had become heated, a tenured faculty member moved for a secret ballot on the committee's recommendation. The main argument offered in favor, by the movant and others, was that, for the protection of untenured professors (who have equal votes with tenured professors on questions of hiring new faculty), neither their senior colleagues nor the Dean should be permitted to know how they voted. The ensuing discussion on whether to hold a secret ballot was no less heated than the original discussion on the committee's recommendation had been. The secret ballot motion was never put to a vote. An open vote on the recommended slate followed.

I left the meeting thinking that something had gone awry, and decided to do some library and empirical/anecdotal research on the importance and prevalence of secret ballots in law

\footnotetext{
${ }^{1}$ Reginald Ezetah, The Right to Democracy: A Qualitative Inquiry, 22 BROOK. J. INT'L L. 495, 516 (1997) (quoting the Universal Declaration of Human Rights, G.A. Res. 217A, at 71, U.N. GAOR, 3d Sess., pt. 1, 183d plen. mtg. U.N. Doc. A/810, art. 21(3) (Dec. 10, 1948)).
} 
school faculty personnel decision-making. As the reader can see, the literature on secret ballots in academic decision-making was relatively sparse, but still easy enough to locate and to present. For the empirical/anecdotal research, I decided early on simply to poll the law schools in the Washington, D.C. vicinity (from Northern Virginia to Baltimore) to determine what their practices were and to report the results in a memorandum to my colleagues. I fully expected, perhaps naively, to find that all of the schools used secret ballots—-particularly when requested by a member of the voting faculty — for faculty hiring, retention, promotion, and tenure decisions, and that we were the outlier. But I did not find that uniformity (would all law schools ever be uniform about anything?). Rather, I learned that, while most, but not all, of the schools I had contacted used secret ballots for faculty personnel matters, there were many variations regarding secret ballot procedures themselves. So instead of writing a memo to my colleagues based on this limited sample, I decided to contact administrators and professors at all 168 AALS member law schools in the United States and 22 of the 23 AALS non-member fee-paid law schools. $^{2}$

I emailed a brief questionnaire, asking about each law school's voting practices on faculty personnel matters. ${ }^{3}$ A majority of the recipients of the questionnaire responded. After reviewing the responses and drafting an early version of this paper, I requested permission from

\footnotetext{
${ }^{2}$ The one non-member school that I did not contact was The Judge Advocate General's School of the U.S. Army, as the school "conducts [only] a graduate legal education program." See http://www.jagcnet.army.mil/JAGCNETINTERNET/HOMEPAGES/AC/TJAGSAWEB.NSF/Main?OpenFrameset (last visited Apr. 21, 2006).

${ }^{3}$ I asked the following questions: (1) Does your school ever use a secret ballot in making faculty hiring, retention, promotion, and/or tenure decisions?; (2) If so, does a faculty member have to request a secret ballot, or is it automatic?; (3) Do you use secret ballots for any other matters?; (4) If so, does a faculty member have to request a secret ballot, or is it automatic?; (5) Does your school have a written policy regarding open vs. secret ballots? (If so, may I review a copy of the policy statement or the provision of the law school or university manual?); (6) If your school allows a secret ballot for faculty personnel (or other) decisions, would you say that this process has been more productive or more counter-productive? Why? [Would you please share any anecdotes to illustrate your conclusion?]; and (7) If your school does not allow a secret ballot for faculty personnel (or other) decisions, would you say that this process has been more productive or more counter-productive? Why? [Would you please share any anecdotes to illustrate your conclusion?]
} 
all respondents whose language I was interested in quoting. As I describe later in this Article, the responses showed many variations in voting policies and practices. This should not be surprising, however, for there were many variations even in responses to my request for permission to quote. Deans and faculty across the country fell into four groups regarding that request: (1) permission granted, with attribution to both the respondent and the law school; (2) permission granted, with anonymity for the respondent, but not for the law school; (3) permission granted, with anonymity for both the individual and the school; and (4) permission denied. ${ }^{4}$ This last category struck me as a bit odd—not because some respondents did not want me to quote their personal opinions, which is perfectly understandable, but because some of them did not want to be quoted even regarding the (I thought) straight-forward question of whether or not their schools used secret or open ballots. And then there was the irresistible irony: some respondents who advocated open ballots_-primarily to hold individuals answerable for their positions - declined to allow use of their names in this Article. ${ }^{5}$

Sometime during the drafting of the Article, I decided that I needed more specific information than the original questionnaire had elicited. I sent a second questionnaire to deans and faculty asking - in the categories of hiring, retention, promotion, tenure, and dean selection —-whether the school used secret ballots; whether the ballots were completely secret, or instead whether faculty members had to sign the ballot or provide reasons; and whether use of the secret ballot was automatic or had to be requested. I also asked whether the school used secret ballots for any other purposes. After several requests with follow-up emails, to my

\footnotetext{
${ }^{4}$ I use different citation forms for the different categories - except, of course, for the fourth category, from which I did not quote at all.

${ }^{5}$ Nevertheless, I am exceedingly grateful to all faculty and administrators who took the time to think about and respond to my questionnaire, whichever category they fell into. This Article would have been impossible to write without their participation and (usually) cooperation.
} 
delight, if not outright astonishment, I received replies from 165 (of 168) AALS member schools and 20 (of 22) non-member schools-for a 97\% response rate. ${ }^{6}$

What began as a one-month assignment to myself turned out to be a year-long project. Undoubtedly this Article will not be the final word on the use of secret ballots for law school faculty personnel decisions. Perhaps other researchers will gather more detailed information in the future. And perhaps they will parse that information differently and find and emphasize other nuances. The results of this project, however, answered my initial query about the prevalence of secret ballots. Perhaps equally important, the email exchanges and conversations I had with faculty and administrators across the country reveal a subtext that involves, among other things, candor, collegiality, openness, fairness, and sensitivity, on the one hand, as well as politics, frustration, anger, power, dominance, and control, on the other hand.

\section{INTRODUCTION}

One of the most important ingredients in a democracy is the secret ballot. ${ }^{7}$ A true democracy emphasizes the will of the people, ${ }^{8}$ and secret voting ensures this touchstone. ${ }^{9}$ Today, the United States government guarantees "[e]very American . . . the right to a secret

\footnotetext{
${ }^{6}$ I summarize the responses later in the Article. See infra Part III.B (describing numerical results); Appendix A ("Numerical Summary"); Appendix B ("Use of Secret Ballots in Law School Faculty Personnel Decisions: School by School Tabulations"); Appendix C ("Comments and Other Uses").

${ }^{7}$ See Julia A. Wentz, Comment, Balancing Academic Freedom and Civil Rights: Toward an Appropriate Privilege for the Votes of Academic Peer Review Committees, 68 IowA L. REV. 585, 593-94 (1983) (noting that the Advisory Committee on the Federal Rules of Evidence recognizes "that secret voting is essential to democratic government and that the right to vote secretly would be meaningless if disclosure could be compelled after the ballot had been cast"); see also Andrew Coleman \& Jackson Maogoto, Democracy's Global Quest: A Noble Crusade Wrapped in Dirty Reality?, 28 SUFFOLK TRANSNAT'L L. REV. 175, 196 (2005) (acknowledging the secret ballot as a key criterion for free and fair elections).

${ }^{8}$ See Ezetah, supra note 1, at 514-15 (arguing that a government is not democratic unless it is based on the consent of the governed).

${ }^{9}$ See, e.g., Saul Levmore, Law, Economics, \& Norms: The Anonymity Tool, 144 U. PA. L. REV. 2191, 2219-20 (1996) (stating that the secret ballot has essentially become a "universal human 'right' " and should become a legal norm in all democratic societies); Erik Van Hagen, Note, The Not-So-Secret Ballot: How Washington Fails to Provide a Secret Vote for Impaired Voters as Required by the Washington State Constitution, 80 WASH. L. REV. 787,787 (2005) (asserting that a secret vote represents the true will of the people because they do not have to fear reprisal for their views).
} 
ballot so that no one - not husband or wife, not parents, not employer . . knows how a voter votes."10 This secrecy enables citizens to express their private opinions freely, without infliction of even the subtlest influence, ${ }^{11}$ and without fearing reprisal from those who vote or think differently. $^{12}$

Just as our nation seeks to protect the unfettered will of its citizens in choosing political leaders, many universities also follow this democratic tradition. University faculty members have a professional responsibility to evaluate their peers and participate in academic governance. ${ }^{13}$ Although faculty do not have a constitutional right to a secret ballot when they make hiring, retention, promotion, and tenure decisions, many schools recognize the importance of truthfulness and conscientiousness in these evaluations and, therefore, generally have professors cast secret ballots for these critical faculty personnel determinations. ${ }^{14}$ The academic community, represented by well-respected organizations such as the American Association of

\footnotetext{
${ }^{10}$ Bernice Powell Jackson, Protecting the Secret Ballot, WiTNESS FOR JUSTICE, Sept. 27, 2004, http://www.ucc.org/justice/witness/wfj092704.htm.

${ }^{11}$ See Van Hagen, supra note 11, at 787-88 ("The purpose of a secret vote is to counteract a great class of evils, including ... the fear of ridicule and dislike, or of social or commercial injury - all coercive influence of every sort depending on a knowledge of the voter's political action.") (citation and internal quotation marks omitted). ${ }^{12} I d$.

${ }^{13}$ See Neil Hamilton, Zealotry And ACAdEmic Freedom 159 (1995) (arguing that professional academic freedom requires university faculty members to review their peers and that this system of self-governance is unique to academia).

${ }^{14}$ See Michael L. Seigel, On Collegiality, 54 J. Legal EduC. 406, 416 (2004) (emphasizing that universities tend to govern themselves based on democratic principles); E-mail from Dennis Arrow, Professor of Law, Oklahoma City University School of Law, to Adrienne Belyea, Washington College of Law (Oct. 13, 2005, 09:01:18 EST) (on file with author) ("To most of us, I believe, [the unvarying rule mandating the secret ballot for personnel decisions is] congruent with the 'secret ballot' premises of the American electoral system, and in my own judgment (and, I believe, that of most of my colleagues), the rule has been productive (even where I and/or any of my colleagues have personally disagreed with the result)."). See also Association of American Law Schools, Report of the AALS Special Committee on Tenure and the Tenuring Process, 42 J. LEGAL EDUC. 477, 499 (1992) (recognizing that many law schools have the secret ballot in place to "encourage honest votes and [to] help eliminate 'back scratching' and fear"). See infra Part III.B (discussing results of primary research conducted by the author); Appendix A; Appendix B; Appendix C. But see University of Pennsylvania v. EEOC, 493 U.S. 182, 200 (1990) (stating that "confidentiality is not the norm in all peer review systems" (citing G. Bednash, The Relationship Between Access and Selectivity in Tenure Review Outcomes (1989) (unpublished Ph.D. dissertation, University of Maryland)).
} 
University Professors (AAUP),${ }^{15}$ the American Council on Education (ACE),${ }^{16}$ and the National Commission on Issues in Higher Education, ${ }^{17}$ recommends this level of confidentiality to encourage candor and to facilitate selection of the most qualified candidates.

While some critics argue that the secret ballot impedes faculty self-governance decisions by not holding professors accountable for their votes,${ }^{18}$ this Article contends that law schools can implement mechanisms to discourage professors from voting with improper motives. Further, it argues that all law schools should use a strict or modified secret ballot system for faculty hiring, retention, promotion, and tenure decisions because the secret ballot best ensures that professors cast votes on academic grounds, and not out of fear of reprisal from the administration or their colleagues. A confidential vote also facilitates a greater exchange of ideas among the faculty by breaking down political factions and decreasing disharmony — two essential goals at many law schools today. In this Article, I discuss the evolution and significance of the secret ballot. I also briefly examine academic freedom and its impact on academic governance. I address why a secret ballot is the superior voting method for making faculty personnel decisions. I then survey the voting practices of law schools in the United States. ${ }^{19}$ I conclude that a secret ballot or a

\footnotetext{
${ }^{15}$ See Association of American Professors, A Preliminary Statement on Judicially Compelled Disclosures in the Nonrenewal of Faculty Appointments, 67 ACADEME 27, 27 (1981) (stating that the AAUP guidelines maintain a presumption of confidentiality unless the "facts and circumstances raise a sufficient inference that some impermissible consideration was likely to have played a role" in the non-renewal decision).

${ }^{16}$ See John A. Gray, Confidentiality of Faculty Peer Review in the Tenure Process, 11 EDUC. LAW REP. 11, 25-26 (1983) (quoting an ACE report that concluded, "[M]ost educators believe that confidentiality encourages candor and openness in the evaluation of individuals under review and therefore is crucial to that process: Confidentiality can strengthen professional equity of treatment as distinct from results achieved through favoritism or popularity .... Confidentiality can promote intellectual excellence, when it allows candor without injury to feeling.") (internal quotation marks omitted).

${ }^{17}$ See Summary Recommendations, National Commission on Higher Education Issues, To Strengthen Quality in Higher Education 9 (Nov. 1982) ("[I]n the evaluation of faculty members, confidentiality is essential to frank and candid assessments of professional qualifications.").

${ }^{18}$ See infra Part II.A.3 (discussing critiques of the secret ballot system).

${ }^{19}$ See supra notes 2-6 and accompanying text (describing research method). Since there is no cognizable difference between the necessity for a secret ballot in the law school and the broader university settings, the compiled law school results also reflect the trends and concerns of university governance. The responses from law school faculty and administrators thus are interspersed throughout the Article, as well as in Part III.A infra.
} 
variant thereof allows the faculty to vote their true sentiments - thus enhancing the quality of the faculty, generating a more enriched dialogue among them, and improving legal education and its impact on our society.

\section{BACKGROUND}

\section{A. Evolution of the Secret Ballot as a Key Ingredient to Democracy}

The official secret ballot system, also known as the Australian ballot, ${ }^{20}$ was an election process created in Australia during the $1850 \mathrm{~s}^{21}$ Australia adopted this system to end the bribery and chaos that surrounded their elections. ${ }^{22}$ Pursuant to this process, a voter received a ballot paper and retreated to a private, inner compartment to strike out the candidates whom he did not want to elect. ${ }^{23}$ Upon completing the ballot, the voter folded the paper and deposited it in a locked box guarded by officials so that the vote would remain anonymous. ${ }^{24}$

Shortly after Australia introduced the secret ballot, politicians in the United States began to campaign for its adoption in the American electoral system. ${ }^{25}$ Corruption, intimidation, and bribery infused nineteenth-century America's open voting system. ${ }^{26}$ Groups of drunk or armed men traveled to various voting stations on Election Day and overtly disclosed their votes in the presence of awaiting voters to intimidate them into casting their ballots for a particular

\footnotetext{
${ }^{20}$ See LiOnel E. Fredman, The Australian Ballot: The StORy of AN American Reform 4 (East Lansing, 1968) (recognizing that the two terms are interchangeable).

${ }^{21}$ See id. at 7 (explaining that William Nicholson, a former Mayor of Melbourne, Australia, drafted the secret ballot provisions that the legislature included in the Electoral Act passed on March 19, 1856; Nicholson is known as the "father of the [secret] ballot").

${ }^{22} \mathrm{Id}$. at 10 .

${ }^{23}$ See id. at 8-9 (indicating that South Australia eventually replaced this method with a process whereby the voter marked a cross within a square next to the name of the candidate for whom he chose to vote). The United States adopted this process rather than the system of striking out names. Id. at 9.

${ }^{24}$ See id. at 9 (stating that officials endorsed strict guidelines that prevented anyone from leaving the room with any papers, to ensure that an individual's vote remained private).

${ }^{25}$ See infra text notes 30-34 and accompanying text (discussing how the American electoral process transitioned from a system in which citizens cast open votes to one in which they cast secret ballots).

${ }^{26}$ See infra text accompanying notes 26-29 (explaining that corruption and intimidation infused the American electoral process before the implementation of the secret ballot system).
} 
candidate. ${ }^{27}$ In addition, candidates engaged in corrupt tactics, such as vote-buying. ${ }^{28}$

Supporters of the secret ballot hoped that it would substantially reduce the influence of money and power in the election process and ensure the honest, considered vote of the people. ${ }^{29}$

In 1888, advocates of the Australian ballot persuaded the State of Massachusetts to implement the first secret ballot system in the United States. ${ }^{30}$ During the next half-century, all of the states adopted the secret ballot, culminating in 1950 when South Carolina was the final state to approve that form of voting. ${ }^{31}$ Since then, voters have been able to cast their ballots in private without having any obligation to party leaders, even if they engaged in "implicit vote contract[s]." ${ }^{, 32}$ Among other things, the secret ballot discouraged candidates and party leaders from engaging in vote-buying, because they were no longer able to "monitor the voters' actions." ${ }^{33}$ Commentators consider the adoption of the secret ballot system to be "one of the greatest gains for democracy in America," because it eliminated the disruptive voting practices present in the open voting process. ${ }^{34}$

\section{B. Academic Freedom: Shielding Professors from Unfair Influence}

\footnotetext{
${ }^{27}$ Richard M. Valelly, The Changing Shape of the American Electorate: Suffrage Laws and Turnout, in AMERICAN PResidential CAmpaigns And Elections 9, 14 (William G. Shade \& Ballard C. Campbell eds., Sharpe Reference 2003).

${ }^{28}$ See Jack Hitt, Real Campaign-Finance Reform, N.Y. TIMES, July 25, 1999, at $§ 6$ (Magazine), p. 36 (describing the process whereby party bosses bought voters and "drove them to the voting stations like cattle"). The bosses further reinforced their purchases by forcing the voters to waive above their heads the colored ballots indicating the candidate for whom they had voted. Id.

${ }^{29}$ Valelly, supra note 27, at 14.

${ }^{30}$ See Sweezy v. New Hampshire, 354 U.S. 234, 266 (1957) (Frankfurter, J., concurring) (discussing how the government did not adequately protect secrecy in the electoral system until it adopted the Australian ballot in 1888).

${ }^{31}$ See Hitt, supra note 28, at 36 (discussing that vote-buying in American elections finally came to an end in 1950, when all of the states formally adopted the secret ballot).

${ }^{32}$ See Jac C. Heckelman, Revisiting the Relationship Between Secret Ballots and Turnout: A New Test of Two LegalInstitutional Theories, 28 AM. POL. Q. 194, 195 (2000) (stating that, since party leaders could not determine which candidate a person voted for, even if the person agreed beforehand to vote for a specific candidate, the party leaders could not enforce these agreements).

${ }^{33} I d$.

${ }^{34}$ Valelly, supra note 27, at 14. But see FREDMAN, supra note 20, at 10 (suggesting that the secret ballot system was not flawless). Party agents were still able to engage in a discreet vote-buying process where voters were sent in one at a time, and the first voter deposited a blank vote and returned with the actual ballot. Id. The agent filled out the ballot and presented it to the next voter in line, who deposited that vote in the box and returned with another unfilled ballot. $I d$. The agent then paid the voter and the process continued. Id.
} 
Courts and commentators have recognized the importance of shielding citizens' thoughts and expressions from government intrusion not only in the political arena, but also in the academic realm. Universities play a unique and critical role in society by advancing ideas, ${ }^{35}$ providing expert advice to civic leaders, ${ }^{36}$ and training our nation's youth. ${ }^{37}$ To allow the academy to excel in these responsibilities, the Supreme Court has recognized that, like our nation's electorate, professors need constitutional protection from government and societal influence as they embark on these vital duties. ${ }^{38}$ Thus, the Supreme Court has held that the First and Fourteenth Amendments provide both universities and individual professors the right to express ideas freely without government intrusion or distrust. ${ }^{39}$ Justice Frankfurter, in a concurring opinion, articulated this concept of constitutional academic freedom as allowing all universities to decide "on academic grounds who may teach, what may be taught, how it shall be taught, and who may be admitted to study."40

Many scholars have argued that a constitutionally-based academic freedom protects faculty members both from the arbitrary influence of the government and from potential coercion by university administrators. ${ }^{41}$ But the Supreme Court rejected this position in University of

\footnotetext{
${ }^{35}$ See Keyishian v. Board of Regents, 385 U.S. 589, 603 (1967) (referring to universities as the "marketplace of ideas") (internal citation and quotation marks omitted); Sweezy, 354 U.S. at 250 (maintaining that scholarship will not flourish and society will not advance unless professors and students can freely study, evaluate, inquire, and understand issues without outside influence).

${ }^{36}$ See American Association of University Professors, The 1915 General Declaration of Principles 155, 158 (1915), reprinted in HAMILTON, supra note 13, app. A, at 368.

${ }^{37}$ See Sweezy, 354 U.S. at 250 ("No one should underestimate the vital role in a democracy that is played by those who guide and train our youth.").

${ }^{38}$ See, e.g., Keyishian, 385 U.S. at 603 (stating that the First Amendment protects academic institutions from laws that inhibit the flow of ideas or that seek to broadly regulate academic institutions).

${ }^{39}$ See Betsey Nathan, The Second Circuit Strikes a Balance Between Academic Freedom and Individual Employment Rights: Gray v. Board of Higher Education, 50 BROOK. L. REV. 627, 644 (1984) (describing the nexus that the Supreme Court developed between the First Amendment and academic freedom over a period of ten years in the context of government accusations of communist activities in American universities).

${ }^{40}$ Sweezy, 354 U.S. at 263 (Frankfurter, J., concurring) (quoting The Open Universities in South Africa 10-12).

${ }^{41}$ See, e.g., James H. Brooks, Confidentiality of Tenure Review and Discovery of Peer Review Materials, 1988 BYU L. REV. 705, 711 (1988) (asserting that academic freedom protects professors' "who may teach" decisions from both the influence of the administration and forces outside the institution).
} 
Pennsylvania v. EEOC, ${ }^{42}$ in which it clarified that constitutional academic freedom protects professors only against government coercion and not against intrusive administrators. ${ }^{43}$ While the Constitution does not protect faculty members from the influence of university administrators and boards of trustees, professional academic freedom does. Specifically, it protects faculty members from employer interference with "research, teaching, and intramural and extramural utterance." ${ }^{44}$ Faculty formed the AAUP in 1915 to contest university interference with individual professors' free speech rights; ${ }^{45}$ the organization has provided professors with the "exceptional vocational freedom to inquire, to teach, and to publish without [administrative] interference." ${ }^{.46}$

Faculty self-governance and peer review are indispensable components of the tradition of academic freedom that exists in our country. ${ }^{47}$ Faculty members have a professional and ethical duty to ensure that universities hire, retain, promote, and tenure only those professors who are dedicated to advancing knowledge both inside and outside of the classroom. ${ }^{48}$ A sound process to evaluate new hires and probationary faculty is critical, because it has a direct impact on the quality of an academic institution and in turn on the intellectual growth of the larger society. ${ }^{49}$ Although professional academic freedom does not categorically require confidentiality in this

\footnotetext{
42493 U.S. 182 (1990) (holding that the First Amendment only protects universities and professors from direct government control over the content of university speech).

${ }^{43}$ See Hamilton, supra note 13, at 187 (contending that the Supreme Court made it clear in University of Pennsylvania v. EEOC, 493 U.S. 182, 200 (1990), that the Constitution does not protect individual faculty members from administrative interference).

${ }^{44}$ See id. (stating that, unlike constitutional academic freedom, professional academic freedom protects faculty from university administrators interfering with their scholarship, speech, and teaching).

${ }^{45}$ See id. at 159 (explaining that professors formed the AAUP at the turn of the century when universities were interfering with professors' abilities to speak freely).

${ }^{46} I d$.

${ }^{47}$ See id. at 163 (maintaining that academic freedom requires faculty self-governance because only professors can evaluate the professional qualifications that are necessary to promote intellectual inquiry and scholarship).

${ }^{48} \mathrm{See} i \mathrm{id}$. (noting that academic freedom places a corresponding duty on professors to govern themselves and to promote academic freedom).

${ }^{49}$ See Gray, supra note 12, at 16 (arguing that, since the "quality of a college is directly dependent on the quality of its faculty, tenure decisions are the most important decisions made each year at institutions of higher education").
} 
decision-making process, many professional associations ${ }^{50}$ and writers ${ }^{51}$ recommend

confidentiality to ensure candor and to guarantee that professors make personnel decisions on

academic grounds, and not based on fear of reprisal from the administration or other faculty

members. Many institutions of higher education have heeded these recommendations and use a

secret ballot system in personnel and other academic governance decisions. ${ }^{52}$

\title{
II. Benefits of the Secret Ballot System in Faculty Personnel Decisions
}

\author{
Determining "who may teach" is arguably the most important issue protected by
}

academic freedom and the most critical matter on which university faculty members vote. ${ }^{53}$

\footnotetext{
${ }^{50}$ See supra notes 15-17 and accompanying text (explaining that the AAUP, the ACE, and the National Commission on Issues in Higher Education all recommend using the secret ballot to encourage candor when making faculty hiring and retention decisions).

${ }^{51}$ See, e.g., Don Mark North, Note, University of Pennsylvania v. EEOC: The Denial of an Academic Freedom Privilege, 18 PEPP. L. REV. 213, 242-43 (1990) (discussing the negative implications of an open voting system on the tenure review process); E-mail from Ronald Chen, Associate Dean for Academic Affairs, Rutgers University School of Law-Newark, to Adrienne Belyea, Washington College of Law (Sept. 16, 2005, 13:52:56 EST) (on file with author) ("I can't imagine that we would ever use a[n] [open] ballot for a faculty personnel decision."). But see E-mail from Lawrence Cunningham, Associate Dean for Academic Affairs, Boston College Law School, to Adrienne Belyea, Washington College of Law (Oct. 9, 2005, 21:15:42 EST) (on file with author) ("[Using the secret ballot] is fine; I doubt any outcome of votes I've been involved with would have changed."); E-mail from Richard Daynard, Associate Dean for Academic Affairs, Northeastern University School of Law, to Adrienne Belyea, Washington College of Law (Sept. 16, 2005, 14:28:45 EST) (on file with author) ("I don't think [using the secret ballot] has made much difference since it was instituted a few years ago."); E-mail from Philip Lacy, Associate Dean for Academic Affairs, University of South Carolina School of Law, to Adrienne Belyea, Washington College of Law (Oct. 12, 2005, 19:26:01 EST) (on file with author) ("I doubt that [the secret ballot] had any impact on either the outcome of the votes or the welfare of the faculty."); E-mail from Lawrence Moore, Associate Dean for Academic Affairs, Loyola University New Orleans School of Law, to Adrienne Belyea, Washington College of Law (Oct. 11, 2005, 12:46:59 EST) (on file with author) ("Overall I doubt whether [a secret ballot] makes much difference in the outcome. At most one or two votes change if they are public."); E-mail from Marshall Tracht, Vice Dean, Hofstra University School of Law, to Adrienne Belyea, Washington College of Law (Oct. 11, 2005, 12:23:37 EST) (on file with author) ("[I]f we did not use [a] secret ballot I don't think it would make much difference."). ${ }_{53}^{52}$ See supra note 14 and accompanying text.

${ }^{53}$ See Association of American Law Schools, supra note 14, at 477 (stating that "[f]aculty renewal is one of the most important responsibilities of the law school. The future quality of the institution depends on the care that is devoted to the initial recruitment of new faculty"). For instance, Dean Warner Lawson of Howard University School of Law stated, "I have been at Howard for 31 years and I have always believed that the vote to hire new faculty is the most important decision the faculty makes." E-mail from Warner Lawson, Associate Dean for Academic Affairs, Howard University School of Law, to Ira P. Robbins, Washington College of Law (Dec. 7, 2005, 18:51:46 EST) (on file with author). The importance of personnel matters in academic governance is illustrated by the practices of many schools that have an open ballot policy for all other issues except hiring, promotion, or tenure decisions. See E-mail from Joan Howarth, Associate Dean for Academic Affairs, University of Nevada Las Vegas, William S. Boyd School of Law, to Adrienne Belyea, Washington College of Law (Oct. 10, 2005, 07:27:31 EST) (on file with author) ("The pertinent portion of our by-laws provides as follows: Voting will be by voice or by show of hands ... except in personnel matters .... In such cases, the vote will be taken by ballot, with the ballots to be
} 
After all, the quality of a university is highly dependent on the quality of its faculty. ${ }^{54}$ Professors drive the flow of ideas both within the classroom and in our society. Further, tenure is a monumental contractual obligation for a university. ${ }^{55}$ It results in a substantial commitment of university resources to a professor, often for thirty or more years. ${ }^{56}$ It is therefore critical for a university to ensure to the greatest extent possible that it hires and tenures only to the most qualified, effective, and productive individuals. ${ }^{57}$

Faculty members are heavily involved in deciding who may teach. ${ }^{58}$ Frequently, the dean appoints or the faculty elects committees or subcommittees to recommend new appointments and

counted at the meeting by the person designated by the presiding officer.") (internal quotation marks omitted); Email from Christine Manolakas, Associate Dean for Academic Affairs, University of the Pacific, McGeorge School of Law, to Adrienne Belyea, Washington College of Law (Oct. 11, 2005, 18:28:58 EST) (on file with author) ("Although not technically automatic, a secret ballot is the tradition for both faculty hiring and promotion/tenure decisions. I cannot remember a secret ballot being used for any other purpose in almost thirty years."); E-mail from Lawrence Moore, Associate Dean for Academic Affairs, Loyola University New Orleans School of Law, to Adrienne Belyea, Washington College of Law (Oct. 11, 2005, 12:46:59 EST) (on file with author) ("[The secret ballot is] automatic for personnel decisions, but otherwise must be requested.").

${ }^{54}$ See supra note 49 and accompanying text (arguing that faculty hiring and retention decisions are the most important decisions made in institutions of higher learning because universities depend on the quality of their faculty for their success).

${ }^{55}$ Frank M. Baglione, Note, Title VII and the Tenure Decision: The Need for a Qualified Academic Freedom Privilege Protecting Confidential Peer Review Materials in University Employment Discrimination Cases, 21 SUfFolK U. L. REV. 691, 702-03 (1987); see also Gray, supra note 16, at 11 (asserting that a university's decision to grant a professor tenure is significant, because it bestows lifetime job security on that professor).

${ }_{57}^{56}$ See Gray, supra note 16, at 11 (assuming that most faculty members are tenured before the age of 35).

${ }^{57}$ Some law schools realize the consequences and commitment that granting tenure carry and possibly take it more seriously by requiring a secret ballot for tenure and promotion, but not for hiring decisions. See E-mail from John Strait Applegate, Executive Associate Dean for Academic Affairs, Indiana University School of Law-Bloomington, to Adrienne Belyea, Washington College of Law (Oct. 10, 2005, 08:28:16 EST) (on file with author) ("Yes [we use a secret ballot], but only for tenure decisions or hiring with tenure."); E-mail from Chris Cameron, Associate Dean for Academic Affairs, Southwestern University School of Law, to Adrienne Belyea, Washington College of Law (Oct. 11, 2005, 10:38:51 EST) (on file with author) ("[We use the secret ballot only] for retention and promotion to tenure decisions."); E-mail from Jethro Lieberman, Associate Dean for Academic Affairs, New York Law School, to Adrienne Belyea, Washington College of Law (Sept. 16, 2005, 14:32:33 EST) (on file with author) ("No (or almost never) in faculty hiring decisions [do we use a secret ballot]. Yes (always) in tenure decisions.”); E-mail from Theresa Newman, Associate Dean for Academic Affairs, Duke University School of Law, to Adrienne Belyea, Washington College of Law (Sept. 16, 2005, 12:03:29 EST) (on file with author) ("[The secret ballot] is automatic for tenure decisions, but has to be requested for other matters.").

${ }^{58}$ See JAMES J. DUDERSTADT, Governing the Twenty-First-Century University, in COMPETING CONCEPTIONS OF ACADEMIC GOVERNANCE 137, 140 (William G. Tierney, ed., 2004) (recognizing that faculty involvement in the hiring process is both "effective and essential" for academic purposes). 
to review and make recommendations on retention, promotion, and tenure, ${ }^{59}$ with the rest of the faculty (or only tenured faculty, for the promotion and tenure decisions) voting on committee recommendations. The future of a school greatly depends on the committees' best collective judgment and the remaining faculty members' honest assessments of the candidates. A confidential review process and a secret ballot system best promote this honesty by encouraging "candid, searching, and rigorous evaluations." 60 A secret ballot also alleviates the conflict and disharmony that often exist among faculty members or between faculty and the administration. ${ }^{61}$

${ }^{59}$ See id. (providing that multiple faculty committees exist within universities, including faculty hiring committees and faculty promotion or tenure committees).

${ }^{60}$ Gray, supra note 16 , at 28 . Most educators agree that confidentiality promotes honesty and openness in the peer review process and therefore is crucial to maintaining that process effectively. $I d$. at 25 . Confidentiality is necessary because it allows the university to treat all candidates equally by eliminating the influences of favoritism and popularity. Id. Many law schools implement a secret ballot system for these reasons. See, e.g., E-mail from M. Thomas Arnold, Associate Dean for Academic Affairs, University of Tulsa College of Law, to Adrienne Belyea, Washington College of Law (Sept. 23, 2005, 15:25:29 EST) (on file with author) ("[One of the] advantages to the secret ballot [is that] people can truly vote their conscience.”); E-mail from Eric Gouvin, Associate Dean for Academic Affairs, Western New England College School of Law, to Adrienne Belyea, Washington College of Law (Sept. 16, 2005, 14:19:05 EST) (on file with author) (stating that the secret ballot is productive because "people tend to vote more honestly on the merits of the candidate"); E-mail from Shauna Marshall, Academic Dean, University of California, Hastings College of Law, to Adrienne Belyea, Washington College of Law (Sept. 17, 2005, 09:00:07 EST) (on file with author) ("I believe [the secret ballot] has worked well. I am sure, from time to time, there are members of the faculty who profess to support a candidate and then vote differently but that does not appear to outweigh the value of the secret ballot."); E-mail from law school official who requested anonymity, to Adrienne Belyea, Washington College of Law (Oct. 12, 2005, 18:35:52 EST) (on file with author) ("With respect to hiring [and promotion and tenure] decisions, our rule reads: 'Voting ... shall be by secret written ballot. A faculty member, whose presence and participation have been by other means pursuant [our rule on proxy voting], may make arrangements to protect the anonymity of his or her vote to the extent feasible.'”); E-mail from Dayna Matthew, Associate Dean of Academic Affairs, University of Colorado School of Law, to Adrienne Belyea, Washington College of Law (Oct. 13, 2005, 16:33:41 EST) (on file with author) ("[The secret ballot is productive] because it encourages candor in [a] safe environment."); E-mail from Martha Spence, Associate Dean for Academic Affairs, Lewis \& Clark Law School, to Adrienne Belyea, Washington College of Law, Dec. 8, 2005, 8:49:58 EST (on file with author) ("[Use of the secret ballot for faculty personnel decisions is] mostly productive in the same way that any voting should be secret - otherwise people might not feel free to vote their true views, but might vote 'politically' or in response to pressure from certain colleagues. Of course, with secret ballots, people can vote 'strategically,' too, but in the 13 years I've been here, I think our process has worked very well and very fairly."); Email from law school official who requested anonymity, to Adrienne Belyea, Washington College of Law (Oct. 11, 2005, 11:41:18 EST) (on file with author) ("[S]ecret ballots permit more truthful reflection [and] assessment than some might be willing to share in an open ballot.").

${ }^{61}$ See Seigel, supra note 14, at 416 (maintaining that many tenured professors on law school faculties view their dean as their equal, and therefore conflict occurs when they want to vote contrary to the dean's opinion); E-mail from Michael S. Ariens, Associate Dean for Academic and Student Affairs, St. Mary's University School of Law, to Adrienne Belyea, Washington College of Law (Sept. 16, 2005, 13:39:42 EST) (on file with author) (finding the secret ballot productive for faculty personnel decisions because "such decisions are fraught with interpersonal conflicts"); E-mail from M. Thomas Arnold, Associate Dean for Academic Affairs, University of Tulsa College of Law, to Adrienne Belyea, Washington College of Law (Sept. 23, 2005, 15:25:29 EST) (on file with author) ("'One 


\title{
A. The Secret Ballot Encourages Faculty Candor and Eliminates the Chilling Effect
}

\author{
A secret ballot voting system for personnel decisions greatly benefits both universities
}

and society in general because it dispels the chilling effect that open voting systems have on

faculty candor. ${ }^{62}$ An open voting system has the capacity to induce faculty members to refrain

from voting; it also has the capacity to chill faculty from giving "honest, candid criticism of

another in public because of the fear that in some way their comments will be misunderstood and

misused by others in their community and because of the fear that in some undefined way there

is the potential for some kind of reprisal against them." ${ }^{.63}$ As a result, personnel decisions made

in an open voting system often do not reflect the faculty's best collective judgment. ${ }^{64}$

of the] advantages of the secret ballot [is that] it probably minimizes hard feelings after votes on very controversial issues."); E-mail from D. Benjamin Beard, Associate Dean, University of Idaho College of Law, to Adrienne Belyea, Washington College of Law (Sept. 16, 2005, 09:11:31 EST) (on file with author) ("We have a small faculty. Voting outside of the 'mainstream' is generally more difficult in smaller groups - the secret ballot ameliorates some of that concern."); E-mail from Kathleen Boozang, Associate Dean, Seton Hall University School of Law, to Adrienne Belyea, Washington College of Law (Oct. 13, 2005, 17:29:09 EST) (on file with author) (“[The secret ballot] is absolutely more productive. It eliminates actual knowledge about who voted how, unless people speak before the vote, and diminishes hard feelings and gossip."); E-mail from Ann Carlson, Academic Associate Dean, University of California at Los Angeles School of Law, to Adrienne Belyea, Washington College of Law (Sept. 16, 2005, 09:07:13 EST) (on file with author) ("The upside [of the secret ballot] is that people can vote freely without fearing political ramifications."); E-mail from Richard Daynard, Associate Dean for Academic Affairs, Northeastern University School of Law, to Adrienne Belyea, Washington College of Law (Sept. 16, 2005, 14:28:45 EST) (on file with author) ("[F]olks feel more comfortable with [the secret ballot]."); E-mail from Carol Goforth, Associate Dean, University of Arkansas School of Law-Fayetteville, to Adrienne Belyea, Washington College of Law (Sept. 16, 2005, 12:16:53 EST) (on file with author) (articulating her preference for secret ballot because it alleviates faculty "fear that negative votes will be reported back to the candidate, and might poison or harm future relationships"); Email from W. Clark Williams, Associate Dean for Academic Affairs, University of Richmond School of Law, to Adrienne Belyea, Washington College of Law (Sept. 16, 2005, 15:38:56 EST) (on file with author) ("[The secret ballot] reduces the chances of resentment or ill feelings that can come from such a significant decision.”); E-mail from law school official who requested anonymity, to Adrienne Belyea, Washington College of Law (Oct. 11, 2005, 09:25:16 EST) (on file with author) ("Information about the faculty members who cast negative votes generally gets back to the person whose tenure or promotion is at issue, and this has resulted in some awkwardness and hard feelings."). But see E-mail from Charles W. Sorenson, Associate Dean, New England School of Law, to Adrienne Belyea, Washington College of Law (Sept. 16, 2005, 17:13:16 EST) (on file with author) (hypothesizing that the open ballot "tempered potential hyper critical faculty members and the tendency for personal animosity to affect votes").

${ }^{62}$ North, supra note 51, at 216-18; see also John D. Copeland \& John W. Murry, Jr., Getting Tossed From the Ivory Tower: The Legal Implications of Evaluating Faculty Performance, 61 Mo. L. REV. 233, 312 (1996) (criticizing open voting systems because they restrict deliberations and prevent the "free and open exchange of opinions and information that is necessary to the deliberative process").

${ }^{63}$ Gray, supra note 16, at 29; see Levmore, supra note 9, at 2222-23 (supporting the idea that open voting may be appropriate in social settings but not necessarily in a more formal environment such as a faculty meeting). A common social setting includes the situation in which one asks a group where to go out to dinner or what movie to 


\section{An Open Voting System Creates a Chilling Effect on Faculty Candor}

There are many reasons why faculty members may refrain from voting altogether or may vote contrary to their honestly held beliefs in an open voting system. Open voting may dissuade professors who, for example, want to remain in the good graces of the dean from participating in the faculty selection or peer review process for fear that their opinions, no matter how legitimate, may be in opposition to the administration's views, and therefore might lead to reprisals against them. ${ }^{65}$ The university setting is particularly democratic; while the dean may be primus inter pares, faculty members accentuate the pares and view themselves as nothing less than equals to the dean and faculty administrators. ${ }^{66}$ Open voting undermines this equality, however, by unduly empowering administrators. ${ }^{67}$ Since the dean controls the salary, committee assignments, and budgetary allotments for all faculty members — as well as course assignments and class schedules - many tenured faculty members may hesitate to disclose a vote that is contrary to the dean's position. This result is irreconcilable with the essence of academic freedom and

see. Id. Obviously, a secret ballot vote in this situation would be ludicrous, "implying fear of reprisal among friends." Id. However, it is not necessarily the case that all faculty members are friends. Instead, among faculty, there are hierarchal relationships, differences between tenured and untenured faculty, and various animosities that may be present.

${ }^{64}$ Gray, supra note 16 , at 11.

${ }^{65}$ See Brooks, supra note 41, at 734 (cautioning that, if faculty members are not assured confidentiality in the peer review process, many faculty members will refuse to vote, fearing that their opinions could be disliked by deans or department chairpersons); E-mail from John Paul Christoff, Associate Dean for Academic Affairs, Ohio Northern University-Claude W. Petit College of Law, to Adrienne Belyea, Washington College of Law (Oct. 11, 2005, 10:47:58 EST) (on file with author) ("[The secret ballot is] productive. Each faculty member should be free to vote his/her conscience without fear of offending the dean (whose preferences may or may not be known).”); E-mail from Kevin Johnson, Associate Dean of Academic Affairs, University of California, Davis School of Law), to Adrienne Belyea, Washington College of Law (Sept. 15, 2005, 15:46:09 EST) (on file with author) ("[The secret ballot is] productive - it allows for a vote without fear of repercussion."); E-mail from William Mock, Associate Dean for Academic Affairs, The John Marshall Law School, to Adrienne Belyea, Washington College of Law (Sept. $16,2005,14: 45: 59$ EST) (on file with author) ("[The secret ballot] has been productive, and widely recognized as such, in that it allows votes of conscience, not pressure from administration or colleagues."); E-mail from law professor who requested anonymity, Penn State University, Dickinson School of Law, to Adrienne Belyea, Washington College of Law (Sept. 16, 2005, 16:31:47 EST) (on file with author) (relating that "some faculty may prefer a secret ballot because they believe that the Dean can seek retribution for their voting").

${ }^{66}$ See Seigel, supra note 14, at 416 ("In theory, faculty members and administrators exercise shared authority over the formulation of policy, procedures, and operating decisions.").

${ }^{67}$ Levmore, supra note 9, at 2222. 
undermines the purpose of tenure, which is to protect faculty members from retaliation by the administration for espousing unpopular ideas. ${ }^{68}$ If a dean can retaliate against a tenured professor for voting in a way that is adverse to his or her wishes_-for example, by withholding a salary increase, program funding, or appointment to a particular committee-one must question how the open voting system preserves the essential goal of academic freedom. ${ }^{69}$

The pressure to vote in accordance with the beliefs of the dean or senior faculty members to avoid reprisal or castigation is even more pervasive among untenured faculty. ${ }^{70}$ Because

\footnotetext{
${ }^{68}$ E-mail from Alan Chen, Professor of Law, University of Denver Sturm College of Law, to Ira P. Robbins, Washington College of Law (Mar. 24, 2006, 11:40:47 EST) (on file with author) ("Under [our] rules, if a single faculty member calls for a closed ballot, one must be held. The rationale for this rule, which other schools have as well, is that if even a single person feels chilled by a non-anonymous vote, it should be done by secret ballot."); Email from law professor who requested anonymity, to Ira P. Robbins, Washington College of Law (Dec. 8, 2005, 20:05:21 EST) (on file with author) ("We have a full discussion of candidates, or other issues, before we vote. Motions, such as to promote someone, are clearly made publicly. I like the idea of secret ballots, however, because it takes away any reality or perception of the possibility of retaliation for one's vote. I should note that I don't believe we have any instances of retaliation for one's vote, but sometimes discussions are highly charged. Especially non-tenured members of the faculty (who vote on employment decisions at [our law school]) feel protected and freer to vote as they choose with a secret ballot.") In a slightly different context, in situations in which faculty members are voting for a new dean from a pool that contains one or more internal candidates, many law schools that typically use an open ballot for other hiring decisions mandate the use of the secret ballot. See E-mail from Glenda Pierce, Associate Dean, University of Nebraska College of Law, to Adrienne Belyea, Washington College of Law (Sept. 16, 12:23:57 EST) (on file with author) ("The only time a secret ballot has been used is for voting on the candidates for dean when there is an internal candidate."). The justification for this change in procedure is that the individual who is ultimately chosen to be the new dean could retaliate against those that did not vote affirmatively for his or her selection.

${ }^{69}$ See Brooks, supra note 41, at 709 (citing Ralph Fuchs, Academic Freedom-Its Basic Philosophy, Function, and History, 28 LAW \& CONTEMP. PROBS. 431 (1963)); cf. National Labor Relations Board, Protection of Your Rights, http://www.nlrb.gov/nlrb/shared files/brochures/election.asp (last visited Apr. 21, 2006) (stating that, due to the high potential that union employers can place undue influence on their employees in union elections, union elections require a secret ballot vote).

${ }^{70}$ Since untenured faculty account for $65 \%$ of all faculty appointments in institutions of higher learning, this presents a serious problem. American Association of University Professors, supra note 36; see E-mail from M. Thomas Arnold, Associate Dean for Academic Affairs, University of Tulsa College of Law, to Adrienne Belyea, Washington College of Law (Sept. 23, 2005, 15:25:29 EST) (on file with author) ("[One of the] advantages to the secret ballot [is that] junior [especially untenured] faculty do not feel at risk in voting. I know for a fact that untenured faculty sometimes feel very vulnerable when it comes to controversial matters."); E-mail from Bruce Berner, Associate Dean for Academics, Valparaiso University School of Law, to Adrienne Belyea, Washington College of Law (Oct. 11, 2005, 11:19:19 EST) (on file with author) ("The value of [the secret ballot] process I believe is a protection of younger colleagues."); E-mail from John Paul Christoff, Associate Dean for Academic Affairs, Ohio Northern University-Claude W. Petit College of Law, to Adrienne Belyea, Washington College of Law (Oct. 11, 2005, 10:47:58 EST) (on file with author) ("Each faculty member should be free to vote his/her conscience without fear of offending ... tenured faculty (in the case of untenured faculty, whose tenure is decided by tenured faculty vote)."); E-mail from Darryll Jones, Associate Dean of Academic Affairs, University of Pittsburgh School of Law, to Adrienne Belyea, Washington College of Law (Oct. 11, 2005, 16:00:09 EST) (on file with author) ("The [secret ballot] policy was implemented out of concern for untenured faculty who may take what
} 
untenured faculty serve in a probationary status at the discretion of the tenured faculty, they are "necessarily beholden" to them for continued appointment. ${ }^{71}$ As a result, untenured facultymore so than their tenured colleagues — necessarily feel greater trepidation in expressing their opinions. $^{72}$ Since society expects professors to be "deeply engaged with colleagues and administrators on a myriad of controversial educational issues,"73 untenured faculty may face devastating repercussions if they vote in opposition to their senior colleagues' positions under an open voting system. The ultimate consequence is that a faculty committee or the dean may deny tenure to a faculty member who voted contrary to the wishes of others on a faculty personnel (or other) matter. ${ }^{74}$ At one undergraduate institution, for example, an untenured history professor refused to vote in accordance with his department chair who believed that the university should reserve a seat within the department for a woman. ${ }^{75}$ Instead, the professor advanced the politically unpopular notion that the seat should go to the most qualified candidate, regardless of

some would view as [a] controversial or unpopular stance on an issue that would not otherwise be subject to secret ballot."); E-mail from Philip Lacy, Associate Dean for Academic Affairs, University of South Carolina School of Law, to Adrienne Belyea, Washington School of Law (Oct. 12, 2005, 19:26:01 EST) (on file with author) ("The thought is that a secret ballot on hiring decisions protects junior faculty members who might fear [publicly] disagreeing with senior members of the faculty."); E-mail from Phillip McIntosh, Associate Dean for Academic Affairs, Mississippi College School of Law, to Adrienne Belyea, Washington College of Law (Oct. 10, 2005, 15:17:51 EST) (on file with author) ("Faculty members prefer [a] secret ballot so as to avoid any undue pressure, particularly on untenured faculty who are voting on hiring issues."); E-mail from Lawrence Moore, Associate Dean for Academic Affairs, Loyola University New Orleans School of Law, to Adrienne Belyea, Washington College of Law (Oct. 11, 2005, 12:46:59 EST) (on file with author) ("[The secret ballot] does protect untenured members of the faculty.”); E-mail from Brian Shannon, Associate Dean for Academic Affairs, Texas Tech University School of Law, to Adrienne Belyea, Washington College of Law (Sept. 16, 2005, 14:37:04 EST) (on file with author) ("I believe that untenured faculty may feel less pressured in voting their minds on hiring decisions with the secret ballot.”); E-mail from Marshall Tracht, Vice Dean, Hofstra University School of Law, to Adrienne Belyea, Washington College of Law (Oct. 11, 2005, 12:23:37 EST) (on file with author) ("[The secret] ballot . . . mitigates any nervousness that untenured faculty may have about someone holding their vote against them."); E-mail from law school official who requested anonymity, to Adrienne Belyea, Washington College of Law (Oct. 10, 2005, 20:26:45 EST) (on file with author) ("The rationale [for using the secret ballot] for entry level hiring is to protect untenured folks from any possibility of intimidation in the tenure process.").

${ }^{71}$ See Benjamin Ernst, David A. Hollinger \& Jonathan Knight, Professors of Practice, 91 ACADEME 60 (Jan. 1, 2005), 2005 WLNR 176897. This document presents the official report of the American Association of University Professors' Committee A on Academic Freedom and Tenure. Id.

${ }^{72}$ See id.

${ }^{73}$ See id.

${ }^{74}$ Seigel, supra note 14 , at $424-26$.

${ }^{75}$ Id. at 425 . 
gender. ${ }^{76}$ As a result of expressing his opinion on what he thought was in the school's best interest, the university later denied the professor a tenured position. ${ }^{77}$ Rather than risk such a fate, many untenured faculty members typically will vote according to how those with power vote, rather than according to the dictates of their own consciences. ${ }^{78}$

Many professors also refrain from voting in a way that is adverse to the views of other professors or the dean for fear that their colleagues or students may misunderstand their votes or use their votes against them in some way. ${ }^{79}$ In one documented situation, students at a university desired to become members of the university's decision-making body. ${ }^{80}$ When students

\footnotetext{
${ }^{76} I d$.

${ }^{77}$ See id. at 424 (noting that there was no other reason why this professor should have been denied tenure, given his strong record as a professor). For instance, by the age of 34, he had graduated from Harvard University and authored 26 works. Id. According to various reports, he "has a first rate teaching record and consistently receives rave reviews from students." Id. (internal quotation marks omitted). His department chair even wrote that, "in every category of measurement - in teaching effectiveness, scholarship, and in service to the department, the college, and the university - [he] has performed in an exemplary manner." Id. (internal quotation marks omitted).

${ }^{78}$ See Wentz, supra note 7, at 585.

${ }^{79}$ See E-mail from Eric Andersen, Associate Dean for Academic Affairs, University of Iowa College of Law, to Adrienne Belyea, Washington College of Law (Sept. 16, 2005, 11:59:54 EST) (on file with author) ("I believe [secret ballot voting for appointments matters and other issues when requested by a member of the faculty] is generally regarded as a positive rule, allowing faculty members to vote their consciences without fear of giving offense or injuring relationships."); E-mail from law school official who requested anonymity, to Adrienne Belyea, Washington College of Law (Nov. 3, 2005, 12:12:14 EST) (on file with author) ("The secret ballot is more productive because faculty feel free to vote their choice without disclosure to their colleagues."); E-mail from Carol Goforth, Associate Dean, University of Arkansas School of Law-Fayetteville, to Adrienne Belyea, Washington College of Law (Sept. 16, 2005, 12:16:53 EST) (on file with author) ("Certainly some negative comments made in the course of discussions have been reported back to candidates, who then must deal with hurt feelings and resentment. And certainly, critical observations in some of our meetings have sometimes strained some relations on the faculty. But not to any great extent, and I think that the faculty credits part of that with our respect for the secret ballot process."); E-mail from law professor who requested anonymity, Penn State University, Dickinson School of Law, to Adrienne Belyea, Washington College of Law (Sept. 16, 2005, 16:31:47 EST) (on file with author) (relating that some faculty may think that "knowledge of who voted against a candidate who ultimately joins the faculty may at some point leak out and affect the relationship of those two colleagues"); E-mail from law school official who requested anonymity, to Adrienne Belyea, Washington College of Law (Oct. 10, 2005, 20:26:45 EST) (on file with author) ("[The secret ballot] prevents people from being able to bully or exert pressure on their colleagues."); E-mail law school official who requested anonymity, to Adrienne Belyea, Washington College of Law (Oct. 12, 2005, 18:35:52 EST) (on file with author) ("[The secret ballot allows] faculty to vote in accordance with true feelings without pressure that their vote will disappoint colleagues, candidates, etc."). But see E-mail from Darryll Jones, Associate Dean of Academic Affairs, University of Pittsburgh School of Law, to Adrienne Belyea, Washington College of Law (Oct. 11, 2005, 16:00:09 EST) (on file with author) ("Some faculty members objected to the inference that untenured faculty would somehow be 'punished' for an unpopular or controversial stance and thought secret ballots 'uncollegial.' ").

${ }^{80}$ See, e.g., Robert T. Blackburn \& John D. Lindquist, Faculty Behavior in the Legislative Process: Professorial Attitudes vs. Behavior Concerning Inclusion of Students in Academic Decision-Making, 44 Soc. OF EDUC. 398, 398
} 
proposed this idea at a joint student-faculty assembly, the majority of faculty — in an open ballot conducted in front of the students—-voted preliminary approval of the proposal. ${ }^{81}$ Two weeks later, however, when the faculty voted on the issue formally through secret ballot, the faculty dismissed the idea. ${ }^{82}$ The possible reasons for this discrepancy exemplify the way in which the open voting system chills honest voting. The presence of the students influenced the faculty because they felt pressure to accommodate the students' desires. ${ }^{83}$ This example illustrates that many faculty members fear becoming unpopular if they vote in a way that is contrary to those around them. Clearly a majority of the faculty did not agree with the students' proposition, but because they did not want to upset the students, the majority either raised their hands or refrained from voting altogether. ${ }^{84}$ This situation is analogous to what happens when a school employs an open voting system for personnel decisions. If a professor hears the dean or a senior colleague whom he or she does not want to alienate espouse a certain stance on an issue, that professor may put his or her beliefs aside and vote along with that person. If the vote is secret, however, faculty are free to vote without this fear of alienation or vindictiveness.

The "show of hands syndrome" is another disadvantage of the open voting system, ${ }^{85}$ in which fence-sitters - faculty who are indecisive on an issue — tend to vote with the majority. ${ }^{86}$ Associate Dean Shirley Mays of Capital University Law School has witnessed this phenomenon: “[P]eople seem to be more willing to vote 'no' on a secret ballot than with a show of hands."

(1971) (discussing the distinguishable voting behavior patterns in an open voting system versus a secret ballot system).

${ }^{81}$ Id. at $399-400$.

${ }^{82} I d$. at 400.

${ }^{83} I d$.

${ }^{84}$ Id. I suspect that there have been similar experiences at many law schools, although I have not specifically inquired.

${ }^{85}$ Id. at 410 .

${ }^{86} I d$.

${ }^{87}$ E-mail from Shirley Mays, Associate Dean of Academic Affairs, Capital University Law School, to Adrienne Belyea, Washington College of Law (Oct. 10, 2005, 10:01:57 EST) (on file with author); see E-mail from law 
As the example in the previous paragraph demonstrates, when the faculty actually voted for the student-generated proposal by secret ballot, the fence-sitters chose to vote a different way. The open voting system thus produced an outcome that was not indicative of each faculty member's true beliefs regarding the best interests of the institution.

Consider another case in point. Dickinson School of Law, prior to and for a while after its merger with Pennsylvania State University (PSU) in 2000, had a tradition of using secret ballots on faculty personnel matters. ${ }^{88}$ With the arrival of a new Dean in 2002, however, the situation changed. One faculty member wrote that, to his credit, the Dean "is leading an aggressive charge to hire 'impact' laterals and to embrace the PSU research model . . .,"89 Another faculty member wrote, "He has been pushing for aggressive recruitment of lateralswhich is great." 90 But this move for aggressive change did not come without controversy. It came, for example, "at a time when we have some significant curricular gaps and when tensions

school official who requested anonymity, to Adrienne Belyea, Washington College of Law (Oct. 11, 2005, 09:25:16 EST) (on file with author) ("The current [open ballot] system may change the default 'neutral' to 'yes' and make it more difficult to cast a 'no' vote, since most cases currently result in an overall 'yes' vote.").

${ }^{88}$ I contacted Penn State-Dickinson professor Francis J. Mootz III in his then-capacity as Associate Dean. Dean Mootz described the Penn State system as contentious and in flux and suggested that he did not wish to be quoted as providing the "official" description of his school's practices because there might be competing views. Subsequently I followed up with inquiries to individual professors and decided that it made sense to report all Penn StateDickinson responses anonymously, although not all professors insisted on it. For overview statements on the use of secret ballots at the school, see, e.g., E-mail from law professor who requested anonymity, Penn State University, Dickinson School of Law, to Ira P. Robbins, Washington College of Law (Dec. 2, 2005, 10:48:48 EST) (on file with author) ("At Penn State Dickinson, for [many] years we have used written ballots on faculty votes taken for personnel decisions, including hiring, promotion and tenure. We also sometimes have used written ballots for matters that were deemed sensitive. We keep written minutes of the meetings and the vote is recorded."). On occasion, the Penn State-Dickinson law faculty has also voted secretly on other issues. For example, "[d] uring the last three years particularly, we have used written ballots when anonymity was requested on clearly sensitive matters, such as votes about the faculty's views on whether we prefer a continuing relationship with Penn State or a realignment with Dickinson College." E-mail from law professor who requested anonymity, Penn State University, Dickinson School of Law, to Ira P. Robbins, Washington College of Law (Dec. 4, 2005, 14:47:57 EST) (on file with author).

${ }^{89}$ E-mail from law professor who requested anonymity, Penn State University, Dickinson School of Law, to Ira P. Robbins, Washington College of Law (Oct. 27, 2005, 16:32:33 EST) (on file with author).

${ }^{90}$ E-mail from law professor who requested anonymity, Penn State University, Dickinson School of Law, to Ira P. Robbins, Washington College of Law (Dec. 2, 2005, 10:48:48 EST) (on file with author). 
between and among faculty and Dean are high." "91 In addition, "some of the recruits, as

wonderful as they are, have been his former colleagues from his previous institution - and in some instances, recruits have been good friends of the dean." 92 As a result of these and other disagreements, "during the second season of voting [after his arrival, the dean] began advocating against secrecy in balloting." 93 Another faculty member wrote, "[t]he Dean has been very vocal about moving to a completely non-secret ballot approach." 94 Indeed, as yet another member of the faculty wrote, "we had been told repeatedly by the Dean that we are the single unit at PSU that has the horrible practice of voting on hiring, promotion and tenure by secret ballot." 95 A faculty member summarized the situation as follows:

\footnotetext{
${ }^{91}$ E-mail from law professor who requested anonymity, Penn State University, Dickinson School of Law, to Ira P. Robbins, Washington College of Law (Oct. 27, 2005, 16:32:33 EST) (on file with author).

${ }^{92}$ E-mail from law professor who requested anonymity, Penn State University, Dickinson School of Law, to Ira P. Robbins, Washington College of Law (Dec. 2, 2005, 10:48:48 EST) (on file with author).

${ }^{93} I d$. Another faculty member reported that the issue was raised almost immediately, but that it has been sharpened in succeeding years. E-mail from law professor who requested anonymity, Penn State University, Dickinson School of Law, to Ira P. Robbins, Washington College of Law (Mar. 25, 2006, 10:00:06 EST) (on file with author).

${ }^{94}$ E-mail from law professor who requested anonymity, Penn State University, Dickinson School of Law, to Ira P. Robbins, Washington College of Law (Dec. 4, 2005, 22:26:43 EST) (on file with author). "The fear is that open ballots will chill individual expression, but the administration keeps assuring the faculty that no retaliation for votes against an administration sponsored candidate." Id.

${ }^{95}$ E-mail from law professor who requested anonymity, Penn State University, Dickinson School of Law, to Ira P. Robbins, Washington College of Law (Dec. 16, 2005, 11:44:29 EST) (on file with author). Another faculty member related that, on another occasion, the Dean had told the faculty that the law school was the only unit in the country that used secret ballots on hiring decisions. E-mail from law professor who requested anonymity, Penn State University, Dickinson School of Law, to Ira P. Robbins, Washington College of Law (Dec. 2, 2005, 14:23:07 EST) (on file with author). Neither assertion, however, is accurate. In fact, in December 2005, "the President of the PSU Faculty Senate conducted a workshop here ... on faculty governance and he was surprised to hear that [the representation about PSU] had been made (the Dean was not present at the meeting)." E-mail from law professor who requested anonymity, Penn State University, Dickinson School of Law, to Ira P. Robbins, Washington College of Law (Dec. 16, 2005, 11:44:29 EST) (on file with author); see also E-mail from law professor who requested anonymity, Penn State University, Dickinson School of Law, to Ira P. Robbins, Washington College of Law (Dec. 19, 2005, 15:41:04 EST) (on file with author) ("[W]e were told last week by the President of the Faculty Senate that ... most units use secret ballots."). One faculty member distilled the situation:

We have had to deal with two different contexts: hiring and promotion/tenure. When PSU departments vote on hiring it is not uncommon for the vote to be by secret ballot. When the P\&T Review Committee votes, however, it is true that the law school may be the only unit that utilizes a secret ballot. However, this is explained by the fact that our P\&T Committee is a Committee of the Whole of tenured faculty members, whereas all other Colleges have a 5-7 person Committee that does the initial review. After vigorous discussion among 5-7 people (from different departments ...), it would be strange to then vote by paper. There is more of a consensus approach, or at least an open delineation of the points of disagreement, and the vote is
} 
The two rationales offered for maintaining the Dickinson Law School (pre-2000 merger) tradition of secret ballots ... were to avoid having untenured or even tenured faculty members believe that there could be repercussions based on their voting, and to avoid having news of a negative vote ever leak out to one's future colleague and make the relationship difficult. The rationale offered by the Dean for public voting is to prevent illegitimate bases for decision-making, including potentially discriminatory voting. ${ }^{96}$

The faculty complied with the Dean's request and put an end to the tradition of secret balloting. "For part of one hiring season, at the new dean's insistence, we adopted open voting on new hires." ${ }^{97}$ This decision did not sit well with some faculty members, however. One consequence was that "[s]ome people either abstained [from voting on hiring matters] or declined to attend hiring meetings because of reluctance to vote openly." " "[M]any of the faculty believ[ed] that voting for the Dean's agenda (including hiring decisions) [was] the way to avoid trouble for oneself." 99

Reconsidering its decision, in the 2004-05 academic year the faculty reversed itself again. ${ }^{100}$ One faculty member wrote, "I see good reasons for anonymity in voting—and dangerous reasons. The last two years have for the first time made me desire anonymous voting

probably not even by a show of hands. However, when the entire tenured faculty enters the room with all its baggage to vote on promotion or tenure, it is a different case.

E-mail from law professor who requested anonymity, Penn State University, Dickinson School of Law, to Ira P. Robbins, Washington College of Law (Mar. 25, 2006, 10:00:06 EST) (on file with author).

${ }^{96}$ E-mail from law professor who requested anonymity, Penn State University, Dickinson School of Law, to Ira P. Robbins, Washington College of Law, (Oct. 27, 2005, 16:32:33 EST) (on file with author).

${ }^{97}$ E-mail from law professor who requested anonymity, Penn State University, Dickinson School of Law, to Ira P. Robbins, Washington College of Law (Dec. 2, 2005, 10:48:48 EST) (on file with author).

${ }^{98} I d$. "My personal opinion is that sometimes negative views are being expressed passively by an[] individual's choice not to attend or send a proxy for the meeting in question. We haven't expressly dealt with this - but we may have to eventually." E-mail from law professor who requested anonymity, Penn State University, Dickinson School of Law, to Ira P. Robbins, Washington College of Law (Dec. 4, 2005, 14:47:57 EST) (on file with author). The Faculty Bylaws provide: "Two-thirds of the faculty constitute a quorum except that persons on sabbatical or authorized leave shall not be counted when determining the pertinent size of the faculty unless such persons are present at the meeting." Bylaws of the Faculty of the Dickinson School of Law, § III (as amended Apr. 19, 2004).

${ }_{99}$ E-mail from law professor who requested anonymity, Penn State University, Dickinson School of Law, to Ira P. Robbins, Washington College of Law (Oct. 27, 2005, 16:32:33 EST) (on file with author).

${ }^{100}$ See E-mail from law professor who requested anonymity, Penn State University, Dickinson School of law, to Adrienne Belyea, Washington College of Law (Sept. 16, 2005, 16:31:47 EST) (on file with author). 
because I personally feel the pressure, even though I'm not easily intimidated."101 But the faculty did not move back to strict secret balloting, for the Dean had stated that "he [would] ignore anonymous negative notes in his calculation, citing the need to protect diversity among faculty ranks, etc." 102 Instead, the faculty adopted a compromise - a secret ballot that is "not anonymous in the full sense, but also without having to reveal one's vote to the Dean or colleagues."103 Under this modified secret ballot approach,

[o]ur current practice is for each voter to sign the written ballots, and the written ballots are to be kept secure by the Office of Human Resources. .. . [T] he dean has agreed to respect this decision. The ballots are read and counted by the chair of the faculty, who is a member of the faculty elected by the faculty. Sometimes the secretary or another individual has helped, with no objection from the faculty. ${ }^{104}$

In fairness to many of the individuals at Penn State-Dickinson who shared information and comments with me, some referred to their situation as "atypical,",105 "somewhat unique,"106 and "a bit in transition, ${ }^{107}$ as the school has gone through a recent merger, is expanding its faculty, and during the past four years has been debating its location and institutional affiliation. ${ }^{108}$ For whatever reasons, however, the school is in flux, at best, or in conflict, at

\footnotetext{
${ }^{101}$ E-mail from law professor who requested anonymity, Penn State University, Dickinson School of Law, to Ira P. Robbins, Washington College of Law (Dec. 2, 2005, 11:45:27 EST) (on file with author).

${ }^{102}$ E-mail from law professor who requested anonymity, Penn State University, Dickinson School of Law, to Ira P. Robbins, Washington College of Law (Oct. 27, 2005, 16:32:33 EST) (on file with author).

${ }^{103} \mathrm{Id}$

${ }^{104}$ E-mail from law professor who requested anonymity, Penn State University, Dickinson School of Law, to Ira P. Robbins, Washington College of Law (Dec. 4, 2005, 14:47:57 EST) (on file with author). "I think our written, signed ballot approach is our current compromise that would permit a candidate who feels unfairly treated the option of discovery in litigation — but at the same time permits some insulation for voters against a perception that we have a very strong dean who leans on people to get his way." Id.

${ }^{105}$ E-mail from law professor who requested anonymity, Penn State University, Dickinson School of Law, to Ira P. Robbins, Washington College of Law (Oct. 28, 2005, 11:05:49 EST) (on file with author).

${ }^{106}$ E-mail from law professor who requested anonymity, Penn State University, Dickinson School of Law, to Ira P. Robbins, Washington College of Law (Dec. 4, 2005, 14:47:57 EST) (on file with author) (due to "relatively recent joinder with Penn State, very recent battles over location, etc.”).

${ }^{107}$ E-mail from law professor who requested anonymity, Penn State University, Dickinson School of Law, to Ira P. Robbins, Washington College of Law (Dec. 4, 2005, 20:35:42 EST) (on file with author).

${ }^{108}$ The school is now proceeding with a two campus approach with buildings in both Carlisle and State College as part of Penn State. E-mail from law professor who requested anonymity, Penn State University, Dickinson School of Law, to Ira P. Robbins, Washington College of Law (Mar. 25, 2006, 10:00:06 EST) (on file with author).
} 
worst, on secret-ballot voting. Even the faculty who urged caution on extrapolating too broadly from the Penn State example saw the common denominator clearly. One wrote: "[I realize that $]$ tensions between administration and faculty probably are always a potential factor for any educational employer deciding who[m] to hire and promote."109 And another wrote: "By saying that our situation is atypical I meant that the issues go well beyond the specific hiring decision. But ... I realize that this is the typical situation to the extent that what is at issue is power."110

\section{Repercussions of the Chilling Effect}

As the Penn State example illustrates, the repercussions of the chilling effect on institutions of higher learning are enormous. Because an academic institution depends on the considered votes of the faculty, and because a candidate's colleagues are the ones who are empowered to evaluate his or her performance, it is essential that faculty members maintain the confidentiality of their votes. ${ }^{111}$ When faculty members fear that the administration will use their votes against them, they may vote for candidates whom they deem to be unqualified or only marginally qualified. ${ }^{112}$ Since a university serves as a primary marketplace of ideas, professors often work together and share information to further the goals of the educational institution and beyond. If a school hires, retains, promotes, or tenures an unqualified or marginally qualified professor, the free exchange of ideas will diminish and the quality of the academic institution as

\footnotetext{
${ }^{109}$ E-mail from law professor who requested anonymity, Penn State University, Dickinson School of Law, to Ira P. Robbins, Washington College of Law (Dec. 4, 2005, 14:47:57 EST) (on file with author).

${ }^{110}$ E-mail from law professor who requested anonymity, Penn State University, Dickinson School of Law, to Ira P. Robbins, Washington College of Law (Oct. 28, 2005, 11:05:49 EST) (on file with author). In fairness to the Dean of Pennsylvania State University, Dickinson School of Law, as well as to the integrity of this Article (and therefore to me), the reader should be aware that several times I invited him comment on matters pertaining to the use of secret vs. open ballots at his school. I have never had a reply.

${ }^{111}$ Brooks, supra note 41, at 733 .

${ }^{112}$ North, supra note 51, at 217-18; see also Brooks, supra note 41, at 706 (reiterating that the release of confidential peer review decisions "would chill [the] tenure debate and promote blandness in the review process," which would almost automatically grant tenure to unqualified candidates); George R. Kramer, Title VII on Campus: Judicial Review of University Employment Decisions, 82 COLUM. L. REv. 1206, 1235 n.148 (1982) (arguing that a secret ballot is essential in the university setting because of the academic institution's need for an "uninhibited assessment" of faculty candidates).
} 
a whole will decrease. ${ }^{113}$ If a university grants tenure for the wrong reasons or promotes an unqualified or marginally qualified professor, for example, this may lead to a decline in the quality of instruction and scholarship at the institution. ${ }^{114}$

\section{Secret Ballot Critiques and Responses}

Opponents of the secret ballot system argue that the potential for discriminatory voting outweighs the chilling effect that the system engenders. Critics postulate that secret voting prevents accountability by permitting faculty members to conceal votes that may be influenced by negative or inappropriate purposes. ${ }^{115}$ Knowing that a secret ballot system protects

\footnotetext{
${ }^{113}$ See Valerie L. Brown, The Confidential Peer Review Process at Institutions of Higher Education: A Case for the Use of a Balancing Test, 41 EDUC. LAW REP. 421, 430 (1988) (stating that, "[w]hen candor diminishes, evaluation becomes less thorough and the value and integrity of the peer evaluation system is eroded").

${ }^{114} I d$. Several law professors and law school officials across the country provided examples of this phenomenon but, to avoid embarrassment to particular colleagues, declined permission to quote or share the story, even anonymously.

${ }^{115}$ See North, supra note 51, at 218; see also E-mail from John Strait Applegate, Executive Associate Dean for Academic Affairs, Indiana University School of Law-Bloomington, to Adrienne Belyea, Washington College of Law (Oct. 10, 2005, 08:28:16 EST) (on file with author) ("The danger of secret ballots is that they permit voters not to express their true reasons openly, which enables (a) ambushing a candidate, or (b) voting against him/her for personal rather than professional reasons, or (c) both."); E-mail from Ann Carlson, Academic Associate Dean, University of California at Los Angeles School of Law, to Adrienne Belyea, Washington College of Law (Sept. 16, 2005, 09:07:13 EST) (on file with author) ("The downside [of the secret ballot] is that sometimes (though infrequently), particularly in a tenure case, a candidate receives negative votes even though no one has articulated reasons for the negative votes."); E-mail from Mayer Freed, Associate Dean for Academic Affairs and Curriculum, Northwestern University School of Law, to Adrienne Belyea, Washington College of Law (Sept. 16, 2005, 15:32:10 EST) (on file with author) ("I feel that our decision to require open voting prevents faculty from pursuing positions, such as political or disciplinary preferences, that they are unwilling to state or defend openly."); E-mail from Darryll Jones, Associate Dean of Academic Affairs, University of Pittsburgh School of Law, to Adrienne Belyea, Washington College of Law (Oct. 11, 2005, 16:00:09 EST) (on file with author) (“Accusations concerning the motives of people based on their [secret] vote are always bandied about but those accusations can never be directed at any particular faculty member."); E-mail from Paul Kurtz, Associate Dean for Academic Affairs, University of Georgia School of Law, to Adrienne Belyea, Washington College of Law (Oct. 10, 2005, 11:13:46 EST) (on file with author) ("There have been times when the secret ballot nature of our voting system has served as a shield for the exercise of unreasoned and unexpressed judgments against the candidacy of various candidates."); E-mail from Shirley Mays, Associate Dean of Academic Affairs, Capital University Law School, to Adrienne Belyea, Washington College of Law (Oct. 10, 2005, 10:01:57 EST) (on file with author) ("[F]aculty promotion/tenure decisions are more productive with an open ballot because it prevents non-legitimate reasons for voting one way or another."); E-mail from William Mock, Associate Dean for Academic Affairs, John Marshall Law School, to Adrienne Belyea, Washington College of Law (Sept. 16, 2005, 14:45:59 EST) (on file with author) ("The possible negative impact [of the secret ballot] relates to the risk of decisions unrelated to enunciated standards, including the possibility that some votes may be cast for unlawful discriminatory reasons."); E-mail from Tamara Piety, Associate Professor of Law, University of Tulsa College of Law, to Ira P. Robbins, Washington College of Law (Mar. 6, 2006, 13:20:17 EST) (on file with author) ("In my opinion, the secret ballot where one doesn't have to give a reason for the vote is pernicious and allows for discriminatory treatment that is hard to ferret out and gives free rein to those who
} 
confidentiality, faculty members who hold biased and subjective motivations may abuse the system, since they do not have to disclose their true intentions for voting in a certain way. ${ }^{116}$ In particular, critics and the courts are concerned with faculty voting that is a result of biases involving race, color, gender, sexual orientation, religion, national origin, or age. In In re Dinnan, ${ }^{117}$ for example - a case involving a denial of promotion to the rank of associate professor and termination of employment at the University of Georgia - the United States Court of Appeals for the Fifth Circuit, in 1981, compelled a member of the Education Promotion Review Committee to disclose his vote, writing that an open voting system would deter only those individuals who are acting pursuant to bad motives and those who are weak-willed. ${ }^{118}$

would make tenure decisions popularity contests rather than decisions on the merits.”); E-mail from law school official who requested anonymity, to Adrienne Belyea, Washington College of Law (Sept. 16, 2005, 10:26:26 EST) (on file with author) ("[The secret ballot] does allow a few faculty the chance to 'get even' and to vote their own personal (petty?) dislikes, without regard to the institutional interest."); E-mail from law school official who requested anonymity, to Adrienne Belyea, Washington College of Law (Oct. 10, 2005, 20:26:45 EST) (on file with author) ("[The secret ballot] creates a danger that the grounds of the decision are not things that people are comfortable saying and therefore that may not be very sound bases for voting."); E-mail from law school official who requested anonymity, to Adrienne Belyea, Washington College of Law (Oct. 11, 2005, 11:41:18 EST) (on file with author) ("[M]y gut tells me that secret ballots mask some result-manipulative behaviors (e.g., ranking who one perceives to be the front-runner the lowest possible so as to assist a less-favorite personal candidate).").

${ }^{116}$ North, supra note 51, at 218 n.46.

${ }^{117} 661$ F.2d 426 (5th Cir. 1981).

${ }^{118}$ Id. at 432 (dismissing the necessity of a secret ballot system, for only the cowardly lack the "courage to stand up and publicly account for [their] decision[s]"); see E-mail from Scott Altman, Associate Dean for Academic Administration, University of Southern California Law School, to Adrienne Belyea, Washington College of Law (Sept. 16, 2005, 10:06:18 EST) (on file with author) ("Our norm . . is that anyone who is opposed to a promotion or a hire should say so and give reasons."); E-mail from Margaret Currin, Associate Dean, Campbell University, Norman Adrian Wiggins School of Law, to Adrienne Belyea, Washington College of Law (Oct. 14, 2005, 12:48:35 EST) (on file with author) ("We don't have a policy disallowing secret ballots or speaking to them at all. To date, individual faculty members have been quite open with respect to their positions on hiring decisions."); E-mail from Paul Kurtz, Associate Dean for Academic Affairs, University of Georgia School of Law, to Adrienne Belyea, Washington College of Law (Oct. 10, 2005, 11:13:46 EST) (on file with author) ("There have been times when the secret ballot nature of our voting system has served as a shield for the exercise of unreasoned and unexpressed judgments against the candidacy of various candidates."); E-mail from Lawrence Moore, Associate Dean for Academic Affairs, Loyola University New Orleans School of Law, to Adrienne Belyea, Washington College of Law (Oct. 11, 2005, 12:46:59 EST) (on file with author) (“"TT]enured faculty members hide behind a secret ballot."); Email from Todd D. Rakoff, Vice Dean for Academic Programming, Harvard Law School, to Adrienne Belyea, Washington College of Law (Sept. 19, 2005, 15:15:12 EST) (on file with author) ("I would say the faculty is mixed on [the secret ballot's] value - some think that it allows people to vote the way they really think by removing social pressures, others think that it promotes irresponsibility."); E-mail from Ronald Rychlak, Associate Dean for Academic Affairs, University of Mississippi School of Law, to Adrienne Belyea, Washington College of Law (Sept. 16, 2005, 12:22:10 EST) (on file with author) ("[The secret ballot] gives people cover to vote without expressing their opinions."); E-mail from Katharine Silbaugh, Associate Dean for Academic Affairs, Boston University School 
Even the strong-willed, however, face adverse consequences if their votes run contrary to the positions of those in power. ${ }^{119}$ Consequently, the most "courageous" faculty members may simply decline to vote altogether or refrain from attending faculty meetings ${ }^{120}$ —neither of which situations is desirable. Although critics claim that the potential for improper motives and cowardly voting are problems unique to secret voting systems, they fail to acknowledge that, even with an open voting system, faculty members could cloak their improper motives (e.g., discrimination, political correctness) behind pretextual reasons for voting against—or for — a particular candidate. $^{121}$

More recent judicial decisions have alleviated the fear that the use of secret ballots facilitates discriminatory motives in faculty hiring and tenure decisions. In University of

of Law, to Adrienne Belyea, Washington College of Law (Sept. 16, 2005, 09:18:22 EST) (on file with author) ("[W]e feel that people deliberate in better faith knowing that they ought to be able to express their reasons for votes."); E-mail from law school official who requested anonymity, to Adrienne Belyea, Washington College of Law (Oct. 10, 2005, 20:26:45 EST) (on file with author) ("The negative [of the secret ballot process] is that people can vote without explaining themselves in any way. Thus a candidate can get a substantial number of no votes, or even be defeated, without people having to say something."); E-mail from law professor who requested anonymity, to Ira P. Robbins, Washington College of Law (Mar. 24, 2006, 15:12:29 EST) (on file with author) ("I believe the secret ballot method is unfair and allows people to hide. I'm in favor of the deliberative process where everyone knows and understands why people have certain opinions about candidates for tenure, promotion or hiring. I believe the legal academe is fraught with unfair processes that other industries would be amazed!!").

${ }^{119}$ In fact, the AAUP has noted with alarm the increasing trend of using a factor based on "collegiality" in making tenure decisions. American Association of University Professors, On Collegiality as a Criterion for Faculty Evaluation, http://www.aaup.org/statements/Redbook/collegia.htm (last visited Apr. 21, 2006). The AAUP warns that using collegiality as a criterion poses a threat to academic freedom:

In the heat of important decisions regarding promotion or tenure, as well as other matters involving such traditional areas of faculty responsibility as curriculum or academic hiring, collegiality may be confused with the expectation that a faculty member display "enthusiasm" or "dedication," evince "a constructive attitude" that will "foster harmony," or display an excessive deference to administrative or faculty decisions where these may require reasoned discussion. Such expectations are flatly contrary to elementary principles of academic freedom, which protect a faculty member's right to dissent from the judgments of colleagues and administrators. A distinct criterion of collegiality also holds the potential of chilling faculty debate and discussion.

Id.

${ }^{120}$ Brooks, supra note 41, at 734 ("After the Third Circuit's decision in EEOC v. Franklin and Marshall College, 705 F.2d 110 (3d Cir. 1985) [denying the existence of an academic freedom privilege], an official at the college stated that, although no one had yet declined to review faculty candidates for fear of disclosure, the possibility 'may not be far off" " (quoting Bitterly, College Prepares to Turn Over Confidential Tenure Files to U.S. Panel, CHRON. HigHER EdUC., Aug. 13, 1986, at 20)). See supra note 98 and accompanying text (discussing situation at Penn State-Dickinson).

${ }^{121}$ The situation is not unlike pretextual reasons that one sees, for example, in adverse employment decisions, in searches and seizures by police at traffic stops, or in peremptory jury challenges. 
Pennsylvania v. EEOC, ${ }^{122}$ the United States Supreme Court formally discarded the idea of a judicially sanctioned academic freedom privilege in employment discrimination cases ${ }^{123}$ and ordered the automatic disclosure of votes in all these cases. ${ }^{124}$ While the Court did not dispute that confidentiality plays an integral role in proper functioning peer review processes, ${ }^{125}$ it ruled that, if a party suspects discriminatory motives, the faculty must disclose their votes during discovery. ${ }^{126}$ " $[\mathrm{I}] \mathrm{f}$ there is a 'smoking gun' to be found that demonstrates discrimination in tenure decisions, it is likely to be tucked away in peer review files." ${ }^{127}$

This decision acts not only as a tool for victims in discrimination suits, but also as a deterrent for potentially dishonest and biased voters. It is unlikely that faculty members, no matter how biased or malicious, would risk having their disingenuous or discriminatory votes disclosed — to the faculty and administration, as well as to the public via the judicial process. ${ }^{128}$ Secrecy is quickly stripped away in litigation, thereby ultimately ensuring accountability for any

\footnotetext{
122493 U.S. 182 (1990).

${ }^{123}$ See North, supra note 51, at 229-31 (stating that the Supreme Court's decision in University of Pennsylvania v. $E E O C$ resolved a circuit split on the extent of the academic freedom privilege in discovery requests for peer review materials by a faculty member alleging employment discrimination). The circuit courts had adopted three different approaches in Title VII employment discrimination cases to determine the extent of the academic freedom privilege when universities used a secret voting system: (1) The Second Circuit weighed academic freedom interests with anti-employment discrimination interests in Gray v. Board of Higher Education, 692 F.2d 901 (2d Cir. 1982); (2) the Seventh Circuit recognized a qualified academic freedom privilege in EEOC v. University of Notre Dame du Lac, 715 F.2d 331(7th Cir. 1983); and (3) the Third and Fifth Circuits denied any academic freedom privilege in EEOC v. Franklin and Marshall College, 705 F.2d 110 (3d Cir. 1985), and In re Dinnan, 661 F.2d 426 (5th Cir. 1981), respectively. Id. The Seventh Circuit ruled most favorably toward the academic freedom privilege and expressly recognized it as fostering "candid, critical, objective and thorough" evaluations in the peer review process. Univ. of Notre Dame du Lac, 715 F.2d at 336.

${ }^{124}$ See University of Pennsylvania, 493 U.S. at 193-94 (rejecting the University's argument that the academic freedom privilege allows it to divert Title VII claims).

${ }^{125} \mathrm{Cf}$. id. at 193 (deciding that the Court did not need to rule on whether confidentiality is instrumental to the proper functioning of the peer review process, as the university had argued).

${ }^{126} I d$.

${ }^{127} \mathrm{Id}$.

${ }^{128}$ While one could argue that, upon disclosure, a faculty member who had voted with malicious or discriminatory intent could merely articulate some legitimate, non-discriminatory reason for voting against a particular candidate, the same argument could be made under the open voting system. In the latter system, however, the faculty member's position would have to be aired; in the former, it would not.
} 
non-academic bases for decisions. While it is easy to offer a pretextual decision, the litigation process works to pierce the pretext.

So the employment-bias criticism may well be a red herring. The sexism, racism, or other discriminatory bias exhibited in faculty voting is typically not of a crude variety, but rather reflects a more subtle reading of résumés, publications, and promotion/tenure files through clouded lenses; open or closed voting usually won't matter much, therefore, because the voting faculty member sees the world in a particular way and (contrary to the perceptions of his or her colleagues) is not just skulking in the shadows waiting to cast a mean-spirited vote. The key is to have robust debate on the facts so that these clouded judgments can be cleared, to the extent possible.

Thus, the secret ballot is not a carte blanche for those who act with inappropriate purposes. Nevertheless, to reduce the possibility of voting based on improper motives, some schools have implemented modified secret ballot systems. For hiring decisions, for example, several law schools require signed secret ballots, which faculty members may view upon request. $^{129}$ At least one school requires that a faculty member must make this request to the entire faculty; most faculty members refrain from asking to see the votes for fear that their peers will shame them. ${ }^{130}$ This system, therefore, compels only those faculty members who truly believe that discriminatory voting has occurred to request to view the individual ballots. ${ }^{131}$ Under this system, however, faculty members still fear retribution from the dean, who could

\footnotetext{
${ }^{129}$ See E-mail from law school official who requested anonymity, to Adrienne Belyea, Washington College of Law (Sept. 15, 2005, 19:33:10 EST) (on file with author) ("For hiring, we sign written ballots so someone who wants to know how particular members of the faculty voted has to ask to see the ballots. This shaming mechanism usually works to keep the ballot secret, but on occasion, a faculty member has asked to see the signed ballots."). This school, however, exercises a strict secret ballot for faculty tenure and promotion decisions. Id. Schools that treat hiring decisions differently from promotion and tenure decisions may give extra weight to the long-term contractual commitment between the school and the tenured professor.

${ }^{130} \mathrm{Id}$.

${ }^{131} I d$.
} 
presumably view the votes without a request, thus rendering the "shaming mechanism" void.

There is a variant of this system at the University of Kansas School of Law, whose hiring policy requires written responses to the dean. "[I]n effect, it's secret from the rest of the faculty but not from the dean."132

Other schools, including the University of Oregon School of Law, also require a signed secret ballot. Votes at Oregon are disclosed only if a legal proceeding arises; the ballots are not accessible to faculty members who wish merely to view them. ${ }^{133}$ Similarly, at Pennsylvania State University, Dickinson School of Law, the ballots for promotion and tenure are secret and unsigned, but (unlike the voting procedure for faculty hiring) any member who votes against a candidate must include the rationale for that decision in the dossier. ${ }^{134}$ As long as a neutral party keeps the votes confidential from faculty members and the dean, these methods remedy critics' fears that secret ballots mask discriminatory motives, while still preserving the benefits of the

\footnotetext{
${ }^{132}$ E-mail from Edwin W. Hecker, Associate Dean for Academic Affairs, University of Kansas School of Law, to Adrienne Belyea, Washington College of Law (Oct. 10, 2005, 16:32:01 EST) (on file with author).

${ }^{133}$ See E-mail from Margaret Paris, Associate Dean for Academic Affairs, University of Oregon School of Law, to Adrienne Belyea, Washington College of Law (Sept. 16, 2005, 16:23:09 EST) (on file with author) ("Ballots are secret but are signed and forwarded to the university provost.").

${ }^{134}$ See E-mail from law professor who requested anonymity, Penn State University, Dickinson School of Law, to Adrienne Belyea, Washington College of Law (Sept. 16, 2005, 16:31:47 EST) (on file with author) ("All votes for tenure and promotion are by secret paper ballot. Under [our] rules, a faculty member voting no must provide a rationale, so that it can be included in the dossier. This can be done by passing this information on to the Chair of the Committee, rather than in the meeting itself."). "The Dean [at Penn State-Dickinson] has announced that he now finds this solution unsatisfactory, and we are heading into some votes on lateral candidates shortly." E-mail from law professor who requested anonymity, Penn State University, Dickinson School of Law, to Ira P. Robbins, Washington College of Law (Oct. 27, 2005, 16:32:33 EST) (on file with author); see also E-mail from Kathleen Boozang, Associate Dean, Seton Hall University School of Law, to Adrienne Belyea, Washington College of Law (Oct. 13, 2005, 17:29:09 EST) (on file with author) ("[W]e save the actual ballots until the Provost/Board approval process is complete in case a question or challenge ever arose."). But see E-mail from Shirley Mays, Associate Dean of Academic Affairs, Capital University Law School, to Adrienne Belyea, Washington College of Law (Oct. 10, 2005, 10:01:57 EST) (on file with author) ("Our promotion/tenure ballots are signed, and must have reasons for the vote.”); E-mail from John Strait Applegate, Executive Associate Dean for Academic Affairs, Indiana University School of Law-Bloomington, to Adrienne Belyea, Washington College of Law (Oct. 10, 2005, 08:28:16 EST) (on file with author) ("It is our custom at Indiana-Bloomington that persons who intend to vote 'no' should explain their views in advance of the vote, and that custom is nearly always honored. Clearly, the purpose of this custom is to avoid secret 'bullet ballots,' and it has nearly always worked."). Since Capital University requires the faculty to provide rationale for "no" votes and sign the ballot and Indiana University-Bloomington compels the faculty to openly explain "no" votes, these processes are much less confidential than those at Seton Hall and other schools. Even though the impetus for all of the policies is to avoid potential legal liability, the benefits of the secret ballot may no longer be preserved at schools with these types of procedures.
} 
secret ballot. These systems respect confidentiality, while providing adequate discovery in employment discrimination litigation, should the occasion arise.

Yet another method to avoid the risk of discriminatory votes, used by Valparaiso University School of Law, is to alter the format of the ballot while still maintaining strict confidentiality. ${ }^{135}$ Instead of a simple yes/no vote, "the ballot forces evaluation on the three criteria of teaching, scholarship and service and disallows a [yes] vote unless there is a positive vote in each category." "136 This approach ensures anonymity, counters the temptation of improper motives, and, ideally, leads to the appointment or retention of the most qualified candidates.

A third variation of an absolute secret ballot allows administrators and professors to identify individual ballots according to different categories, such as tenured or untenured and full or assistant professor. This variation, used at the University of Wyoming College of Law, is inadequate to achieve true, open, and effective voting on faculty personnel decisions, however, since these categories can often destroy confidentiality, especially in small schools. ${ }^{137}$

UCLA School of Law employs yet another variation, allowing its faculty the option to waive its secret ballot requirement on an annual basis. ${ }^{138}$ Even if the faculty waives the secret

\footnotetext{
${ }^{135}$ E-mail from Bruce Berner, Associate Dean for Academics, Valparaiso University School of Law, to Adrienne Belyea, Washington College of Law (Oct. 11, 2005, 11:19:19 EST) (on file with author) ("The tenure and promotion document requires a secret ballot and even specifies its format.").

${ }^{136} \mathrm{Id}$.

${ }^{137}$ See E-mail from Dee Pridgen, Associate Dean, University of Wyoming College of Law, to Adrienne Belyea, Washington College of Law (Sept. 20, 2005, 16:20:13 EST) (on file with author) ("Yes, [we use secret ballots] although votes are identified as coming from full, associate or assistant [professors], and tenured or untenured. We have a really small faculty so these designations can identify some persons."); E-mail from Ann Carlson, Academic Associate Dean, University of California at Los Angeles School of Law, to Adrienne Belyea, Washington College of Law (Sept. 16, 2005, 11:11:28 EST) (on file with author) (quoting The UCLA CALL's Appendix 4 on "Voting Rights-Senate Bylaw 55": "Even though confidentiality would be reduced, it is permissible to report separately the votes of different categories of voting members of the department (tenure, non-tenure, etc.) where such information is considered useful (e.g., to the Council on Academic Personnel or the Administration)."). Due to its vagueness, the term "useful" may provide a danger to confidentiality.

${ }^{138}$ See E-mail from Ann Carlson, Academic Associate Dean, University of California at Los Angeles School of Law, to Adrienne Belyea, Washington College of Law (Sept. 16, 2005, 11:11:28 EST) (on file with author) ("From
} 
ballot in its yearly vote, however, "a secret ballot shall be taken on a specific vote at the request of one or more voting members." 139 This option may be beneficial for a university that has had a long history of open voting but would like to transition to a secret ballot, or for a school that is still apprehensive about potential improper motives. This system gives the faculty an opportunity to see the benefits of a confidential vote without feeling tied down for the long term. Notwithstanding these mechanisms that eliminate potential abuses while preserving the advantages of a secret ballot system, some critics contend that secret ballots hinder communication among faculty members because they do not have an opportunity to discuss openly their opinions on hiring, retaining, promoting, or tenuring candidates. ${ }^{140}$ An open voting system, however, creates similar implications. Faculty members appointed to peer review

the Law School Bylaws: Voting on academic personnel matters is by secret ballot unless the Faculty votes to waive the secret ballot by the following procedure: The Faculty may decide on an annual basis to waive the secret ballot with respect to a given class of personnel actions, provided that this be decided unanimously in a secret ballot of Faculty entitled to vote on that class of personnel action, and provided further that a secret ballot shall be taken on a specific vote at the request of one or more voting member[s]."). Basically, UCLA School of Law follows an absolute secret ballot procedure, unless the faculty unanimously votes to follow Robert's Rules of Order. See infra notes 188-89 and accompanying text (discussing Robert's Rules). Under no circumstances is open voting forced on faculty members who prefer the secret ballot.

${ }^{139}$ E-mail from Ann Carlson, Academic Associate Dean, University of California at Los Angeles School of Law, to Adrienne Belyea, Washington College of Law (Sept. 16, 2005, 11:11:28 EST) (on file with author).

${ }^{140}$ See E-mail from M. Thomas Arnold, Associate Dean for Academic Affairs, University of Tulsa College of Law, to Adrienne Belyea, Washington College of Law (Sept. 23, 2005, 15:25:29 EST) (on file with author) ("I believe that if a person is going to vote for or against someone based on something, it should be something in the record and something the faculty has had an opportunity to incorporate into their deliberations."); E-mail from Mark Kelman, Vice Dean, Stanford University Law School, to Adrienne Belyea, Washington College of Law (Sept. 16, 2005, 10:27:16 EST) (on file with author) (“Open balloting leads to the effort to reach something closer to a consensus."); E-mail from Michelle Simon, Associate Dean for Academic Affairs, Pace University School of Law, to Adrienne Belyea, Washington College of Law (Sept. 16, 2005, 13:18:26 EST) (on file with author) ("[The secret ballot] allows [faculty] to be silent ...."); E-mail from Katharine Silbaugh, Associate Dean for Academic Affairs, Boston University School of Law, to Adrienne Belyea, Washington College of Law (Sept. 16, 2005, 09:18:22 EST) (on file with author) ("Although an open vote may have costs in highly political cases, especially for untenured faculty, on balance open balloting is superior because it encourages deliberations and defensible positions."); E-mail from Michael Solimine, Associate Dean for Faculty Development, University of Cincinnati College of Law, to Adrienne Belyea, Washington College of Law (Sept. 19, 2005, 14:46:41 EST) (on file with author) ("[S]ome faculty have felt that the secret ballot practice has been counterproductive ... by what they see as the arguable dampening of discussion during meetings that culminated in a secret ballot."); E-mail from Charles Tabb, Associate Dean, University of Illinois College of Law, to Adrienne Belyea, Washington College of Law (Oct. 10, 2005, 05:48:37 EST) (on file with author) ("[P] eople believe it is crucial for all views to be aired in public."); E-mail from law school official who requested anonymity, to Adrienne Belyea, Washington College of Law (Nov. 3, 2005, 10:40:19 EST) (on file with author) ("[O]n balance open balloting is superior because it encourages deliberations and defensible opinions."). 
committees, for example, often compromise their beliefs out of fear that their opinions will

create confrontational situations among the faculty or that their colleagues will retaliate against them if their opinions do not coincide. ${ }^{141}$ Consequently, many peer reviews will lead to promotion or tenure where faculty members wish to vote against a candidate, but refrain from doing so when others are voting affirmatively. ${ }^{142}$ Thus, ironically, an open voting system may actually decrease the value of the communication. ${ }^{143}$ If there is an open ballot that is leading to "groupthink"-i.e., uncritical acceptance of or conformity to prevailing points of view-there will also be less deliberation. Everyone will be looking to the signal from the Powers That Be concerning how to act. If the secret ballot doesn't promote greater conversation (and, as described above, I think it does), then at a minimum there would be an opportunity for each individual to vote on the merits after the groupthink discussion has concluded.

Also, granting tenure to too many unqualified or marginally qualified candidates, instead of awarding this status only to those who most merit it, threatens to decrease the "teaching

${ }^{141}$ Brooks, supra note 41 , at 734.

${ }^{142}$ Id.; see E-mail from Mark Kelman, Vice Dean, Stanford University Law School, to Adrienne Belyea, Washington College of Law (Sept. 16, 2005, 10:27:16 EST) (on file with author) ("I suspect over the course of the 28 years that I have been here at Stanford that there may have been tenure votes that could have turned out negative ... in secret ballots that were affirmative in open balloting because of fear of having one's negative vote disclosed to the candidate, though I certainly can't identify any particular cases in which I believe that to be true."); E-mail from Mae Kuykendall, Senior Associate Dean for Academic Affairs, Michigan State University College of Law, to Adrienne Belyea, Washington College of Law (Oct. 10, 2005, 22:36:57 EST) (on file with author) ("There have been occasional stealth votes against tenure and against a candidate. If the votes were public, the phenomenon could not occur."); E-mail from Jethro Lieberman, Associate Dean for Academic Affairs, New York Law School, to Adrienne Belyea, Washington College of Law (Sept. 16, 2005, 14:32:33 EST) (on file with author) ("Secret ballots on tenure allow faculty members to dissent in private from the tendency to support the decision of a committee, which is the body recommending to the tenured faculty the application of a candidate for tenure. I believe that it is productive, not counterproductive [to use a secret ballot]. We occasionally deny tenure, though in my memory we have never overturned a committee recommendation. What the secret ballot produces, though, is a larger (usually negative) vote than probably would otherwise occur."); E-mail from Shirley Mays, Associate Dean of Academic Affairs, Capital University Law School, to Adrienne Belyea, Washington College of Law (Oct. 10, 2005, 10:01:57 EST) (on file with author) (“[P] eople seem to be more willing to vote no on a secret ballot than with a show of hands."); E-mail from law school official who requested anonymity, to Adrienne Belyea, Washington College of Law (Oct. 11, 2005, 09:25:16 EST) (on file with author) ("The current [open ballot] system may change the default vote from 'neutral' to 'yes' and make it more difficult to cast a 'no' vote, since most cases currently result in an overall yes vote."); E-mail from law school official who requested anonymity, to Adrienne Belyea, Washington College of Law (Sept. 16, 2005, 10:26:26 EST) (on file with author) ("[The secret ballot] does lead to more negative votes.").

${ }^{143}$ Brooks, supra note 41, at 734. 
quality and scholarly excellence among permanent faculty members."144 A report published by the Commission on Academic Tenure in Higher Education further supports these arguments. The Commission concluded that the embattled concept of tenure was not due only to the concept itself, but also was partially a result of "serious deficiencies in its application and administration" $" 145$ that allow less-than-qualified individuals to be granted tenure. ${ }^{146}$ If universities are to maintain academic excellence using peer evaluation, professors must make faculty hiring and retention decisions "deliberately and carefully . . f free from the undue external pressure" that open voting inevitably creates. ${ }^{147}$

Moreover, a secret ballot does not hinder communication because many schools still hold open discussions before the matter goes to a secret vote. Those faculty members who hold conflicting views have the opportunity (but are not required) to voice their opinions, exchange ideas, and even lobby other faculty to adopt their viewpoint. The controlling difference is that, with a secret ballot, in the end each individual can cast his or her ballot considering the discussion, yet free from the influence of colleagues or administrators who choose to voice their opinions openly. ${ }^{148}$

\footnotetext{
${ }^{144} I d$.

${ }^{145}$ Commission on Academic TenURe IN Higher Education, Faculty Tenure 20 (1973).

${ }_{146}^{146}$ Brooks, supra note 41, at 735 .

${ }^{147}$ See American Association of University Professors, Statement on Procedural Standards in the Renewal or Nonrenewal of Faculty Appointments, POLICY DOCUMENTS \& REPORTS 14, 16-17 (1984).

${ }^{148}$ See E-mail from Dennis Arrow, Professor of Law, Oklahoma City University School of Law, to Adrienne Belyea, Washington College of Law (Oct. 13, 2005, 09:01:18 EST) (on file with author) ("Within our Promotion and Tenure Board . . . all retention, promotion, and tenure decisions are . . voted on by secret ballot. We respect that tradition so much that we adhere to it even where the discussion makes it apparent that everyone will likely (or certainly) be voting 'yes.' "); E-mail from Jeffrey Berman, Associate Dean, University of Missouri-Kansas City School of Law, to Adrienne Belyea, Washington College of Law (Sept. 16, 2005, 11:37:01 EST) (on file with author) ("[Our secret ballot policy has had a] neutral effect, since the debate prior to the vote often reveals the voting proclivity anyway."); E-mail from Ann Carlson, Academic Associate Dean, University of California at Los Angeles School of Law, to Adrienne Belyea, Washington College of Law (Sept. 16, 2005, 09:07:13 EST) (on file with author) (“This is taken from The UCLA CALL's Appendix 4 re 'Voting Rights-Senate Bylaw 55': 'Nothing in these requirements prevents faculty members from making their own vote public.' "); E-mail from H. Miles Foy, Executive Associate Dean for Academic Affairs, Wake Forest University School of Law, to Adrienne Belyea, Washington College of Law (Oct. 11, 2005, 09:27:59 EST) (on file with author) ("[W]e . . . have a practice of soliciting individual oral comments from each member of the faculty concerning the faculty candidate or hiring
} 


\title{
B. The Secret Ballot Decreases Disharmony Among the Faculty
}

\author{
Employing the secret ballot is also important because it may help to alleviate disharmony
}

among the faculty. ${ }^{149}$ This goal is significant because academic excellence relies on collegial

relationships and the free exchange of ideas among faculty members. ${ }^{150}$ Faculty who fear

reprisal or who generally do not associate with one another are not likely to provide feedback on

their colleagues' projects, to discuss teaching methodologies, or observe each other's

decision in question, and thus each faculty member has an opportunity (but not an obligation) to declare his preferences specifically and openly. The individual oral comments are then followed by the secret ballot. My impression is that the system works very well indeed."); E-mail from Edwin W. Hecker, Associate Dean for Academic Affairs, University of Kansas School of Law, to Adrienne Belyea, Washington College of Law (Oct. 10, 2005, 16:32:01 EST) (on file with author) ("We have a full and frank discussion [regarding] promotion/tenure, but then each person is free to vote his/her conscience without fear of gossip getting back to the candidate."); E-mail from Phillip McIntosh, Associate Dean for Academic Affairs, Mississippi College School of Law, to Adrienne Belyea, Washington College of Law (Oct. 10, 2005, 15:17:51 EST) (on file with author) ("The secret ballot is] [p]roductive and essentially noncontroversial. We fully discuss the candidate prior to voting. Faculty members prefer secret ballot so as to avoid any undue pressure."); E-mail from Marshall Tracht, Vice Dean, Hofstra University School of Law, to Adrienne Belyea, Washington College of Law (Oct. 11, 2005, 12:23:37 EST) (on file with author) ("On hiring, we tend to operate on consensus, and if [a] secret ballot is close there will often be a motion [to] reconsider and further discussion so that some more general consensus can be reached."). But see Email from Shirley Mays, Associate Dean of Academic Affairs, Capital University Law School, to Adrienne Belyea, Washington College of Law (Oct. 10, 2005, 10:01:57 EST) (on file with author) ("It has made for some counterproductive hiring decisions where the conversation about the candidate seems fine, then the candidate receives many no votes without explanation.").

${ }^{149}$ See E-mail from Kathleen Boozang, Associate Dean, Seton Hall University School of Law, to Adrienne Belyea, Washington College of Law (Oct. 13, 2005, 17:29:09 EST) (on file with author) ("[The secret ballot] is absolutely more productive. It eliminates actual knowledge about who voted how, unless people speak before the vote, and diminishes hard feelings and gossip.”); E-mail from Edwin W. Hecker, Associate Dean for Academic Affairs, University of Kansas School of Law, to Adrienne Belyea, Washington College of Law (Oct. 10, 2005, 16:32:01 EST) (on file with author) ("[E]ach person is free to vote his/her conscience without fear of gossip getting back to the candidate."); E-mail from Barbara Kritchevsky, Associate Dean, The University of Memphis-Cecil C. Humphreys School of Law, to Adrienne Belyea, Washington College of Law (Oct. 10, 2005, 12:17:52 EST) (on file with author) ("[The secret ballot is] helpful — people are freer to vote their minds without worrying about what will get back to the person involved."); E-mail from law school official who requested anonymity, to Adrienne Belyea, Washington College of Law (Oct. 11, 2005, 09:25:16 EST) (on file with author) ("Information about the faculty members who cast negative votes generally gets back to the person whose tenure or promotion is at issue, and this has resulted in some awkwardness and hard feelings.").

${ }^{150}$ The collegiality that a secret ballot system helps to preserve contributes to maintenance of academic excellence in many ways. Professors who provide valuable feedback on their colleagues' projects help produce better scholarship, which inevitably brings recognition to that school. Seigel, supra note 14, at 411-12 (citing the AALS' statement of good practices by law professors in the discharge of their ethical and professional responsibilities). Similarly, when professors collaborate and discuss different teaching methods, they may improve a law school's or university's reputation for the quality of its faculty. Further, academic excellence also depends on the faculty's participation in committees and their willingness to mentor junior faculty. $I d$. A disharmonious faculty, however, is not inclined to be collegial and thus participate in improving the quality of the law school or university in these or other ways. 
classes. Indeed, they might not talk to each other at all. With a secret ballot on personnel and other sensitive issues, however, the best interests of the school can be nourished and advanced. Under the secret ballot system, faculty members can fulfill their professional duty and vote honestly on what they believe is in the school's best interest without creating confrontational situations. ${ }^{151}$ Further, by not knowing how others vote, a professor cannot get upset at other faculty members if they vote in a way that he or she deems inappropriate or unacceptable. ${ }^{152}$ It is less likely, therefore, that a faculty member would refuse to work with other faculty members, decline to participate on a particular committee, or cast a future vote that is motivated only by spite simply because faculty members do not share the same beliefs_-about law, about legal education, or even about life in general. In essence, over time the secret ballot system may actually lessen faculty factionalization, not increase it. This system, then, is the best means to preserve the collegial relationships ${ }^{153}$ upon which, in part, an academic institution thrives. ${ }^{154}$ As Associate Dean Carol Goforth of the University of Arkansas School of LawFayetteville reported, the secret ballot avoids

\footnotetext{
${ }^{151}$ See David McMillin, Note, University of Pennsylvania v. EEOC and Dixon v. Rutgers: Two Supreme Courts Speak on the Academic Freedom Privilege, 42 RUTGERS L. REV. 1089, 1103 (1990) (citing the concerns expressed by amici curiae of small colleges in EEOC v. Franklin \& Marshall College, 775 F.2d 110 (3d Cir. 1985)); see, e.g., E-mail from William Rich, Associate Dean, Washburn University School of Law, to Adrienne Belyea, Washington College of Law (Sept. 19, 2005, 12:53:43 EST) (on file with author) ("An illustration of helpful use of secret ballots occurred recently when we were making decisions about hiring. It was a contentious issue, the faculty was divided, and some new faculty may have been uncomfortable siding with one group or another. Knowing that we would use a secret ballot helped to alleviate those fears.").

${ }^{152}$ See E-mail from D. Benjamin Beard, Associate Dean, University of Idaho College of Law, to Adrienne Belyea, Washington College of Law (Sept. 16, 2005, 09:11:31 EST) (on file with author) ("[The secret ballot] is more productive because it allows for a more confident selection process with less outside influence from peers. We have a small faculty. Voting outside of the 'mainstream' is generally more difficult in smaller groups - the secret ballot ameliorates some of that concern."). Of course, faculty may express their views openly during the faculty discussion, but that would be by choice.

${ }^{153}$ See E-mail from M. Thomas Arnold, Associate Dean for Academic Affairs, University of Tulsa College of Law, to Adrienne Belyea, Washington College of Law (Sept. 23, 2005, 15:25:29 EST) (on file with author) ("The ...

secret ballot ... probably minimizes hard feelings after votes on very controversial cases."); E-mail from Lawrence Cunningham, Associate Dean for Academic Affairs, Boston College Law School, to Adrienne Belyea, Washington College of Law (Oct. 9, 2005, 21:15:42 EST) (on file with author) (“[The secret ballot] helps collegiality.").

${ }^{154}$ See E-mail from W. Clark Williams, Associate Dean for Academic Affairs, University of Richmond School of Law, to Adrienne Belyea, Washington College of Law (Sept. 16, 2005, 15:38:56 EST) (on file with author) ("[The
} 
fear that negative votes will be reported back to the candidate, and might poison or harm future relationships .... Certainly some negative comments made in the course of discussions have been reported back to candidates, who then must deal with hurt feelings and resentment. And certainly, critical observations in some of our meetings have sometimes strained some relations on the faculty. But not to any great extent, and I think that the faculty credits part of that with our respect for the secret ballot process. ${ }^{155}$

The open voting system, on the other hand, threatens to create and perpetuate disharmony among the faculty. When making personnel decisions, professors aim to provide truthful assessments of a candidate's potential or actual scholarly achievement and teaching effectiveness. ${ }^{156}$ Forcing professors to reveal their votes and thus disclose how they view candidates' qualifications openly, however, may strain indispensable collegial relationships, since inevitably faculty members will hold opposing views and, for example, those faculty members who have been granted tenure will naturally often hold grudges against those who voted against them. ${ }^{157}$ As a result, compulsory open voting on controversial matters often pits

secret ballot] enhances the collegial working relationship among faculty, particularly as to one who may be hired/promoted/tenured with a less than unanimous vote, and with whom ongoing positive relations are, of course, important.").

${ }^{155}$ E-mail from Carol Goforth, Associate Dean, University of Arkansas School of Law-Fayetteville, to Adrienne Belyea, Washington College of Law (Sept. 16, 2005, 12:16:53 EST) (on file with author).

${ }^{156}$ Brooks, supra note 41, at 736 (citing the Report of the Committee on Confidentiality in Matters of Faculty Reappointment, 13 U. CHI. REC. 165, 165-66, 168 (1979)). In fact, academic excellence relies on a peer evaluation system in which personnel decisions are made pursuant to the faculty's honestly held beliefs. See, e.g., supra text accompanying notes 144-46 (stating that granting tenure to unqualified professors threatens to decrease the quality of teaching and scholarship in universities).

157 See Brooks, supra note 41, at 736 ("[S] ome academicians argue that pressure brought by members of the administration on certain faculty members who favor or disfavor a particular tenure candidate might lead to adversarial relationships between the faculty and administration.”). For example, Associate Dean Michael Ariens of St. Mary's University School of Law finds the secret ballot to be productive in faculty hiring decisions because such decisions are fraught with interpersonal conflicts. The tenured faculty took a secret vote on whether to tenure the wife of a tenured colleague. A secret ballot made the consequences of voting one's conscience less severe than an open ballot, for despite the outrage of some faculty members who were friends of the applicant, they could not directly accuse anyone of voting negatively in her case.

E-mail from Michael S. Ariens, Associate Dean for Academic and Student Affairs, St. Mary's University School of Law, to Adrienne Belyea, Washington College of Law (Sept. 16, 2005, 09:07:13 EST) (on file with author) (Dean Ariens was not a member of the law school administration at the time of that vote). Similarly, new faculty hires might hold grudges against senior colleagues who voted against their appointment. 
faculty members against each other ${ }^{158}$ and creates factions among them. ${ }^{159}$ When factions exist and tempers flare, professors may simply refuse to work with one another or may even seek retribution for casting an unpopular vote. ${ }^{160}$ And once factions have developed, open voting only exacerbates the disharmony and alienation among the factions that it helped to create. While a professor may often agree with, and thus vote with, the rest of his or her faction, that is certainly not always the case. And when the professor's assessment is not in accordance with the rest of his or her group, under the open voting system the professor may feel compelled to vote with that group even if he or she has a different viewpoint. To avoid this compulsion and the subsequent disharmony among and even within faculty groups, schools should implement the secret ballot or its functional equivalent, thus allowing the faculty an unfettered vote and more productive and amiable relationships thereafter.

\section{LAW SChOOLS' USE OF SECRET BaLlots}

\section{A. A Range of Views}

Following the recommendations of the academic community and well-respected academic associations, such as the AAUP, ${ }^{161}$ most law schools in the United States recognize the benefits of a secret ballot and implement the system in making various faculty personnel decisions. ${ }^{162}$ Many of these schools use the secret ballot for personnel decisions pursuant to

\footnotetext{
${ }^{158}$ Id.; see E-mail from law professor who requested anonymity, Penn State University, Dickinson School of Law, to Adrienne Belyea, Washington College of Law (Sept. 16, 2005, 16:31:47 EST) (on file with author) (relating that some faculty may think that "knowledge of who voted against a candidate who ultimately joins the faculty may at some point leak out and affect the relationship of those two colleagues"); E-mail from law school official who requested anonymity, to Adrienne Belyea, Washington College of Law (Sept. 16, 2005, 10:26:26 EST) (on file with author) ("But [the secret ballot] does allow a few faculty to get the chance to 'get even' and to vote their own personal (petty?) dislikes, without regard to the institutional interest.").

${ }^{159}$ See Gray v. Board of Higher Educ., 92 F.R.D. 87, 93 (S.D.N.Y. 1981), rev'd, 692 F.2d 901 (2d Cir. 1982).

${ }^{160}$ Gray, supra note 16 , at 29.

${ }^{161}$ See supra notes 15-17 and accompanying text (describing the AAUP's steadfast position that the secret ballot system is the best practice for institutions of higher learning when making faculty hiring and retention decisions).

${ }^{162}$ See Association of American Law Schools, supra note 14, at 499 (noting that it is common at most law schools to use the secret ballot in hiring decisions). See also, e.g., E-mail from Peter-Raven Hansen, Associate Dean for Academic Affairs, George Washington University School of Law, to Sima P. Bhakta, Washington College of Law
} 
school policy, ${ }^{163}$ while others use the practice as a matter of custom. ${ }^{164}$ For instance, the Rules

and Procedures for the Faculty Appointments Process for the College of William \& Mary,

(Mar. 2, 2005, 13:54:25 EST) (stating that all faculty personnel decisions are decided by secret ballot); Telephone Interview by Sima P. Bhakta with Bruce Kobayashi, Associate Dean for Academic Affairs, George Mason University Law School (Mar. 24, 2005) (providing that all faculty decisions are made through secret ballot); E-mail from David Millon, Associate Dean of Academic Affairs, Washington and Lee University School of Law, to Sima P. Bhakta, Washington College of Law (Apr. 6, 2005, 22:01:08 EST) (on file with author) ("[W]e use secret ballots both for faculty hiring and for tenure decisions. This is routine, so no faculty member needs to make a request."); Email from Theresa Newman, Associate Dean for Academic Affairs, Duke University School of Law, to Adrienne Belyea, Washington College of Law (Sept. 16, 2005, 12:03:29 EST) (on file with author) (stating that Duke uses a secret ballot for faculty tenure decisions); E-mail from Todd D. Rakoff, Vice Dean for Academic Programming, Harvard Law School, to Adrienne Belyea, Washington College of Law (Sept. 19, 2005, 15:15:12 EST) (on file with author) (stating that Harvard Law School uses a secret ballot for both hiring and promotion decisions); Telephone Interview by Sima P. Bhakta with Elma Richardson, Executive Assistant to the Dean, Georgetown University Law Center (Mar. 24, 2005) (explaining that faculty appointment and tenure decisions are made by secret ballot); E-mail from W. Clark Williams, Associate Dean of Academic Affairs, University of Richmond Law School, to Sima P. Bhakta, Washington College of Law (Mar. 21, 2005, 17:53:14 EST) (on file with author) ("[W]e do take a ballot vote on personnel/hiring decisions. It is not [prescribed] in [the] Bylaws, but is a longstanding practice at our Law School.").

${ }^{163}$ See, e.g., E-mail from Ann Carlson, Academic Associate Dean, University of California at Los Angeles School of Law, to Adrienne Belyea, Washington College of Law (Sept. 16, 2005, 11:11:28 EST) (on file with author) ("This is taken from The UCLA CALL's Appendix 4 re 'Voting Rights-Senate Bylaw 55': 'The vote on all personnel matters shall be by secret ballot. Procedures should be designed so that only the voter shall know how he or she voted." "); E-mail from John Paul Christoff, Associate Dean for Academic Affairs, Ohio Northern UniversityClaude W. Petit College of Law, to Adrienne Belyea, Washington College of Law (Oct. 11, 2005, 10:47:58 EST) (on file with author) ("The Constitution of the College of [L]aw requires a secret ballot on the acceptability of faculty candidates."); E-mail from Carol Goforth, Associate Dean, University of Arkansas School of LawFayetteville, to Adrienne Belyea, Washington College of Law (Sept. 16, 2005, 14:16:53 EST) (on file with author) ("The following language appears in our personnel document relating to hiring of faculty members: 'The vote shall be by secret ballot, no form of proxy voting shall be allowed, and no candidate for the position under consideration, or for another directly-affected position, shall attend the meeting." "); E-mail from Joan Howarth, Associate Dean for Academic Affairs, University of Nevada Las Vegas, William S. Boyd School of Law, to Adrienne Belyea, Washington College of Law (Oct. 10, 2005, 07:27:31 EST) (on file with author) ("The pertinent portion of our bylaws provides as follows: 'Voting will be by voice or by show of hands . . except in personnel matters .... In such cases, the vote will be taken by ballot, with the ballots to be counted at the meeting by the person designated by the presiding officer.' "); E-mail from Darryll Jones, Associate Dean of Academic Affairs, University of Pittsburgh School of Law, to Adrienne Belyea, Washington College of Law (Oct. 11, 2005, 16:00:09 EST) (on file with author) ("The vote with respect to promotion by tenure is secret by virtue of a simple directive in the faculty handbook that states, 'Vote will be by secret, written ballot. Members may vote yes, no, or abstain.' This phrase is the entire policy.") (internal quotation marks omitted); E-mail from Paul Kurtz, Associate Dean for Academic Affairs, University of Georgia School of Law, to Adrienne Belyea, Washington College of Law (Oct. 10, 2005, 11:13:46 EST) (on file with author) ("University rules require that all votes on promotion and tenure and appointment be taken by secret ballot."); E-mail from Philip Lacy, Associate Dean for Academic Affairs, University of South Carolina School of Law, to Adrienne Belyea, Washington School of Law (Oct. 12, 2005, 19:26:01 EST) (on file with author) ("The [Tenure and Promotion] Procedures state, 'Faculty members shall vote by secret ballot.' "); Email from Brian Shannon, Associate Dean for Academic Affairs, Texas Tech University School of Law, to Adrienne Belyea, Washington College of Law (Sept. 16, 2005, 14:37:04 EST) (on file with author) (“"[O]ur rules state: Hiring: 'All votes taken on appointments and the terms thereof shall be by secret ballot. The ballots shall be counted and the results announced to the faculty at the end of the balloting.' Promotion: 'At the close of the discussion, a secret ballot shall be taken in the case of each candidacy ....' Tenure: 'At the close of the discussion, a secret ballot shall be taken." ") (internal quotation marks omitted); E-mail from law school official who requested anonymity, to Adrienne Belyea, Washington College of Law (Oct. 12, 2005, 18:35:52 EST) (on file with author) 
Marshall-Wythe School of Law state: "Decisions on appointment matters will be made by

Faculty. ... The Faculty will vote by secret ballot on an appointment." ${ }^{165}$ Similarly, the UCLA

Senate Bylaw for voting rights pertaining to personnel decisions provides, "The vote on all

personnel matters shall be by secret ballot. Procedures should be designed so that only the voter

shall know how he or she voted."166 Catholic University’s Columbus School of Law is also

strongly committed to the secret ballot tradition for faculty personnel decisions; indeed, then-

Dean William Fox emphasized that he "would not want this to change-ever!!"167

("With respect to hiring [and promotion and tenure] decisions, our rule reads: 'Voting . . shall be by secret written ballot. A faculty member, whose presence and participation have been by other means pursuant [our rule on proxy voting], may make arrangements to protect the anonymity of his or her vote to the extent feasible.' ").

${ }^{164}$ See, e.g., E-mail from M. Thomas Arnold, Associate Dean for Academic Affairs, University of Tulsa College of Law, to Adrienne Belyea, Washington College of Law (Sept. 23, 2005, 15:25:29 EST) (on file with author) ("To my knowledge, neither our Governance document nor our Promotion and Tenure document expressly require a written, secret ballot for hiring. However, I've been here 25 years and this has [been] our unbending practice. We've never deviated from it."); E-mail from James Devine, Associate Dean for Academic Affairs, University of MissouriColumbia School of Law, to Adrienne Belyea, Washington College of Law (Sept. 18, 2005, 12:10:17 EST) (on file with author) ("I have been here 25 years and we have always used secret ballots for [personnel] purposes."); E-mail from H. Miles Foy, Executive Associate Dean for Academic Affairs, Wake Forest University School of Law, to Adrienne Belyea, Washington College of Law (Oct. 11, 2005, 09:27:59 EST) (on file with author) ("We [use secret ballots] as a matter of custom, and we do it in every case. A faculty member does not have to request or invoke the procedure."); E-mail from Darryll Jones, Associate Dean of Academic Affairs, University of Pittsburgh School of Law, to Adrienne Belyea, Washington College of Law (Oct. 11, 2005, 16:00:09 EST) (on file with author) ("The vote with respect to hiring is secret by longstanding practice, there is no written policy."); E-mail from Cheney Joseph, Vice Chancellor for Academic Affairs, Louisiana State University, Paul M. Hebert Law Center, to Adrienne Belyea, Washington College of Law (Sept. 16, 2005, 14:20:00 EST) (on file with author) ("We have followed for many years a practice of voting on all personnel matters by secret ballot — hiring, tenure, promotion, appointment of visitors, appointment of faculty. The procedure is followed in all cases without a specific request."); E-mail from Warner Lawson, Associate Dean for Academic Affairs, Howard University School of Law, to Adrienne Belyea, Washington College of Law (Sept. 16, 2005, 16:54:23 EST) (on file with author) ("[The secret ballot policy is] automatic, but I think by history-not by rule."); E-mail from Christine Manolakas, Associate Dean for Academic Affairs, University of the Pacific, McGeorge School of Law, to Adrienne Belyea, Washington College of Law (Oct. $11,2005,18: 28: 58$ EST) (on file with author) ("Although not technically automatic, a secret ballot is the tradition for both faculty hiring and promotion/tenure decisions. I cannot remember a secret ballot being used for any other purpose in almost 30 years."); E-mail from W. Clark Williams, Associate Dean for Academic Affairs, University of Richmond School of Law, to Adrienne Belyea, Washington College of Law (Sept. 16, 2005, 15:38:56 EST) (on file with author) ("Not a written policy [on secret ballots], no. But a long-standing practice has been for hiring or [promotion and tenure] decisions, always to be by secret ballot.").

${ }^{165}$ E-mail from Lizbeth Jackson, Associate Dean for Administration, College of William \& Mary Law, MarshallWythe School of Law, Washington College of Law (Mar. 21, 2005, 13:19:31 EST) (on file with author).

${ }^{166}$ E-mail from Ann Carlson, Academic Associate Dean, University of California at Los Angeles School of Law, to Adrienne Belyea, Washington College of Law (Sept. 16, 2005, 11:11:28 EST) (on file with author) ("This is taken from The UCLA CALL's Appendix 4 re 'Voting Rights-Senate Bylaw 55' ”).

${ }^{167}$ E-mail from William Fox, Dean, Catholic University of America, Columbus School of Law, to Eileen M. Flanagan, Assistant to the Dean, to Sima P. Bhakta, Washington College of Law (Apr. 6, 2005, 14:25:46 EST) ("1. We ALWAYS use secret ballot in matters involving faculty personnel. It is non-discretionary in our system 
Other law schools employ the secret ballot system only when a member of the faculty requests it concerning a particular issue. ${ }^{168}$ The University of Maryland School of Law generally votes through open ballot procedures; however, the university's long-standing practice permits any faculty member to request a vote by secret ballot for any issue. ${ }^{169}$ As a matter of collegiality, Maryland grants the faculty member's request without any procedural obstacles or separate votes on whether there should be a secret ballot vote on the issue. ${ }^{170}$ Taking this approach further, some schools that officially have the same written policy as Maryland have evolved in practiceand sometimes in writing, amending the previous policy - to an automatic secret ballot system for personnel decisions, due to the frequency of requests for a secret ballot for these decisions. ${ }^{171}$

under the Handbook. 2. When the faculty votes on things other than personnel matters, we usually use either a 'voice' vote or a 'show of hands.' ").

${ }^{168}$ See, e.g., E-mail from Ediberto Roman, Associate Dean for Academic Affairs, Florida International University, College of Law, to Adrienne Belyea, Washington College of Law (Oct. 10, 2005, 12:40:46 EST) (on file with author) ("A faculty member must request [a secret ballot], (usually before the meeting)."). E-mail from Jethro Lieberman, Associate Dean for Academic Affairs, New York Law School, to Adrienne Belyea, Washington College of Law (Sept. 16, 2005, 14:32:33 EST) (on file with author) ("A request for [a] secret ballot on most issues is usually honored (normally a consensus will develop); I do not recall a request for [a] secret ballot on hiring new faculty."). Dean Lieberman also stated that a secret ballot is used for tenure and promotion decisions. Id.

${ }^{169}$ E-mail from Richard Boldt, Associate Dean for Research and Faculty Development, University of Maryland School of Law, to Sima P. Bhakta, Washington College of Law (Apr. 6, 2005, 12:09:40 EST) (on file with author); see also E-mail from Bruce Berner, Associate Dean for Academics, Valparaiso University School of Law, to Adrienne Belyea, Washington College of Law (Oct. 11, 2005, 11:19:19 EST) (on file with author) ("For hires, [the secret ballot] must be requested. ... [There is no written policy], just a culture of permitting it whenever requested."); E-mail from Gary Maveal, Associate Dean for Academic Affairs, University of Detroit Mercy School of Law, to Adrienne Belyea, Washington College of Law (Sept. 16, 2005, 08:40:49 EST) (on file with author) ("I believe it is customary to agree to secret ballot by request unless someone calls for a vote on that preliminary issue."); E-mail from W. Clark Williams, Associate Dean for Academic Affairs, University of Richmond School of Law, to Adrienne Belyea, Washington College of Law (Sept. 16, 2005, 15:38:56 EST) (on file with author) ("[V]oting will be by secret ballot on any issue if any faculty member requests it [other than hiring, promotion and tenure by which, it is an automatic secret ballot].”).

${ }^{170}$ E-mail from Richard Boldt, Associate Dean for Research and Faculty Development, University of Maryland School of Law, to Sima P. Bhakta, Washington College of Law (May 9, 2005, 10:39:02 EST) (on file with author) (suggesting that the faculty would comply with the request as a matter of collegiality).

${ }^{171}$ See, e.g., E-mail from Jeffrey Berman, Associate Dean, University of Missouri-Kansas City School of Law, to Adrienne Belyea, Washington College of Law (Sept. 16, 2005, 11:37:01 EST) (on file with author) ("Although the Faculty Bylaws provide that 'a secret ballot vote shall be taken whenever requested by any Voting Member' it has been the practice to make the secret ballot [an] automatic one when the vote deals with faculty hiring."'); E-mail from Seth Chandler, Vice Dean of Academic Affairs, University of Houston Law Center, to Adrienne Belyea, Washington College of Law (Sept. 16, 2005, 10:59:34 EST) (on file with author) ("If one faculty member requests it, we use a secret ballot (which means that it almost always occurs)."); E-mail from Barbara Kritchevsky, Associate Dean, The University of Memphis-Cecil C. Humphreys School of Law, to Adrienne Belyea, Washington College of Law (Oct. 10, 2005, 12:17:52 EST) (on file with author) ("Our governing rules provide that any faculty may request 
Consider the maturation of secret-ballot voting at the University of the Pacific, McGeorge

School of Law. The Faculty Bylaws had provided (and still provide) that, on matters of retention, promotion, and tenure, secret ballots are automatic, but on matters of hiring, as well as on any other question, "[v]oting shall be conducted by secret ballot if requested by any voting member and approved by the presiding officer or by one-third of the voting members present at the meeting." 172 McGeorge faculty members reported that—because secret ballots were typically requested on committee recommendations for new hires, and that "in recent memory we have always used secret ballots for hiring decisions" ${ }^{\prime 173}$ — the faculty came to view secret ballots on faculty personnel matters as "routine." ${ }^{, 174}$ Recognizing this evolution, the faculty amended the Bylaws, effective December 1, 2004, to provide for automatic secret ballots on motions to recommend offers of employment, ${ }^{175}$ as well as on motions to prioritize appointments candidates. $^{176}$

Other schools, including the University of Pittsburgh School of Law, recognize that even making a request for a secret ballot can raise suspicions among colleagues and the administration. Therefore, this practice is still vulnerable to the dangers of the open ballot discussed previously. Although the University of Pittsburgh has an automatic secret ballot for

a secret ballot on any vote. The Promotion and Tenure committee generally prepares ballots, assuming we'll vote that way."); E-mail from William Mock, Associate Dean for Academic Affairs, The John Marshall Law School, to Adrienne Belyea, Washington College of Law (Sept. 16, 2005, 14:45:59 EST) (on file with author) ("Technically, it has to be requested, but it has been requested in every vote in memory. In recent years, the Chair of the Selections and Appointments Committee will typically save someone the trouble of making the motion by making the motion him/herself sua sponte.").

${ }^{172}$ Faculty Bylaws on Employment, Promotion, and Tenure, University of the Pacific, McGeorge School of Law. At Chicago-Kent College of Law, secret ballots are not used for hiring or promotion and tenure, unless $25 \%$ of the voting faculty then present vote to do so. See Appendix C.

${ }^{173}$ E-mail from law professor at University of the Pacific, McGeorge School of Law, to Ira P. Robbins, Washington College of Law (Dec. 13, 2005, 11:37:15 EST) (on file with author).

${ }^{174}$ E-mail from Gerald Caplan, Professor of Law, University of the Pacific, McGeorge School of Law, to Ira P. Robbins, Washington College of Law (Dec. 8, 2005, 19:43:11 EST) (on file with author).

${ }^{175}$ Faculty Bylaws on Employment, Promotion, and Tenure, University of the Pacific, McGeorge School of Law, § II.B.2.d (effective Dec. 1, 2004).

${ }^{176} I d$. § II.B.3.b. 
personnel decisions, Associate Dean Darryll Jones discussed a recently implemented method to protect confidentiality and ensure thoughtful, productive decisions on all other issues.

We have recently (about two years ago) adopted a policy whereby any faculty member may request a secret vote on any matter before the faculty. The faculty member .... sends such a request to the Chairperson of the Faculty Steering Committee ... in confidence and the Chairperson must grant the request without divulging the name of the requestor. The faculty member need not divulge his or her identity to the Chairperson. ${ }^{177}$

This point was raised by others as well. A faculty member at another law school wrote:

[W]e recently had an issue on the agenda for our faculty meeting (where secret ballots are at the option of a faculty member) that was somewhat charged.

Several non-tenured members of the faculty asked some of us who are tenured to request a secret ballot. This raises two points: (1) [t]hey perceived the secret ballot as a positive and a way to allow them freedom in voting, and (2) [t]hey preferred to not be the ones to ask for the secret ballot, which perhaps is a flaw in our system if one is disadvantaged by asking for it. ${ }^{178}$

Some schools - including the University of California at Davis School of Law and the University of Iowa College of Law—use a double-blind system for the submission of secret ballots. Iowa also has a non-academic administrator transcribe the ballots, to avoid the recognition of handwriting. ${ }^{179}$ For the same reason, the University of Akron tries to have ballots with the names listed on them to be checked or circled. ${ }^{180}$

Another method that has been employed by at least one law school—the University of Michigan Law School—is the "secret straw vote." Under this system, the eligible faculty vote

\footnotetext{
${ }^{177}$ E-mail from Darryll Jones, Associate Dean of Academic Affairs, University of Pittsburgh School of Law, to Adrienne Belyea, Washington College of Law (Oct. 11, 2005, 16:00:09 EST) (on file with author). Dean Jones further discussed how the policy was first implemented out of concern for untenured faculty members; however, a number of secret ballots have been requested and there is no way to determine whether these requests have come from tenured or untenured faculty. Id.

${ }^{178}$ E-mail from law professor who requested anonymity, to Ira P. Robbins, Washington College of Law (Dec. 8, 2005, 20:05:21 EST) (on file with author).

${ }^{179}$ See Appendix C.

${ }^{180}$ See id.
} 
by secret ballot, the dean announces the results of that secret vote, discussions continue, and then the final governing vote is taken in the open. ${ }^{181}$

Finally, whether based on policy, ${ }^{182}$ tradition $^{183}$ or varying governance structure, ${ }^{184}$ some law schools continue to use an open voting system for all faculty decisions. ${ }^{185}$ Indeed, on a motion for a secret ballot at a recent faculty meeting on hiring, one law school dean is reported to have said, "A secret ballot is anti-democratic!"186

${ }^{181}$ See id.

${ }^{182}$ See, e.g., E-mail from Mayer Freed, Associate Dean for Academic Affairs and Curriculum, Northwestern University School of Law, to Adrienne Belyea, Washington College of Law (Sept. 16, 2005, 15:32:10 EST) (on file with author) ("Our tenure and promotion procedures provide explicitly for an open ballot.").

${ }^{183}$ See, e.g., E-mail from Margaret Currin, Associate Dean, Campbell University, Norman Adrian Wiggins School of Law, to Adrienne Belyea, Washington College of Law (Oct. 14, 2005, 12:48:35 EST) (on file with author) ("We don't have a policy disallowing secret ballots or speaking to them at all. To date, we have never used a secret ballot for hiring decisions."); E-mail from Mayer Freed, Associate Dean for Academic Affairs and Curriculum,

Northwestern University School of Law, to Adrienne Belyea, Washington College of Law (Sept. 16, 2005, 15:32:10 EST) (on file with author) ("There is nothing written regarding hiring decisions, but there is a strong tradition of open voting."); E-mail from Steven Goode, Associate Dean for Academic Affairs, The University of Texas School of Law, to Adrienne Belyea, Washington College of Law (Sept. 16, 2005, 12:07:29 EST) (on file with author) ("We do not use secret ballots and have not for the 28 years that I have been here."); E-mail from Alan Weinberger, Associate Dean for Faculty, Saint Louis University School of Law, to Adrienne Belyea, Washington College of Law (Sept. 21, 2005, 00:08:31 EST) (on file with author) ("Saint Louis University School of Law does not use secret ballots for hiring, promotion or tenure decisions. Hiring decisions are made by open ballot at faculty meetings. Promotion and tenure decisions are made by open ballot at meetings of the Personnel Committee, consisting of all full professors.").

${ }^{184}$ DUDERSTADT, supra note 58, at 139; see, e.g., E-mail from Carol Mon Lee, Associate Dean, University of Hawaii at Manoa-William S. Richardson School of Law, to Adrienne Belyea, Washington College of Law (Oct. 10, 2005, 16:34:01 EST) (on file with author) ("Answers [to the secret ballot questionnaire] pertain to hiring onlytenure is done by committee.").

${ }^{185}$ E-mail from James E. Ryan, Academic Associate Dean, University of Virginia School of Law, to Sima P. Bhakta, Washington College of Law (Mar. 17, 2005, 11:13:45 EST) (on file with author) ("I don't know of any provisions that require or even permit secret balloting. I don't think we have any formal provisions on this issue at all; as a general norm, we do not vote secretly, either in committee or on the floor at faculty meetings.'); E-mail from Michael Klausner, Associate Dean for Research and Academics, Stanford Law School, to Sima P. Bhakta, Washington College of Law (Mar. 17, 2005, 10:59:56 EST) (on file with author) (stating that there are no explicit provisions in the rules that permit secret ballot voting). Dean Klausner also noted that a faculty member's request for a secret ballot would likely not be granted. Id. E-mail from Richard Briffault, Vice-Dean, Columbia Law School, to Sima P. Bhakta, Washington College of Law (Apr. 6, 2005, 12:13:23 EST) (on file with author) (noting that Columbia uses "open voting (and no absentee voting) on personnel decisions, such as hiring of faculty and promotion to tenure, and all other faculty decisions"). However, the faculty of Columbia Law School does use a secret ballot when electing members of the appointments committee and in recommending a candidate for dean of central administration. Id.

${ }^{186}$ Why did you look down here? You don't really expect me to disclose the name of the professor or the law school, do you? E-mail from law professor who requested anonymity, to Ira P. Robbins, Washington College of Law (Sept. 16, 2005, 10:18:25 EST) (on file with author). 
Like the University of Maryland, however, law schools employing an open ballot system should at the very least permit faculty members to make a secret ballot request, and better yet, a confidential request as the University of Pittsburgh allows. Schools that do not have provisions detailing how voting should take place should adopt a policy following Robert's Rules of Order, ${ }^{187}$ according to which a faculty member has an opportunity to assert that the vote take place by secret ballot. ${ }^{188}$ Under Robert's Rules, when a faculty member makes such a request, the faculty would vote — by secret ballot — to determine if the vote on the issue at hand should be decided by secret ballot. ${ }^{189}$ A better and less complicated policy would be to adopt the practice whereby the faculty complies with the request without a separate vote, to maintain the valued and existing respect among faculty members. ${ }^{190}$ In either case, the importance of maintaining good relations and honest votes among colleagues necessitates the need either to follow a strict secret ballot policy or a viable modification thereof (such as a signed ballot that is not revealed unless there is a lawsuit or investigation) for all faculty personnel decisions, or to grant a faculty member's confidential secret ballot request on a particular issue.

\section{B. The Numbers}

\footnotetext{
${ }^{187}$ See Henry M. Robert et Al., Robert's Rules of Order (Perseus, Newly Revised 10th ed. 2000). See also Email from Ivy Broder, Dean of Academic Affairs, American University, to Sima P. Bhakta, Washington College of Law (Mar. 17, 2005, 11:24:43 EST) (on file with author) (noting that, where the regulations are silent on secret ballot provisions, Robert's Rules of Order should govern requests for secret ballot); E-mail from Enid TruciosHaynes, Associate Dean for Academic Affairs, University of Louisville-Louis D. Brandeis School of Law, to Adrienne Belyea, Washington College of Law (Dec. 7, 2005, 14:11:57 EST) (on file with author) ("The Brandeis School of Law at the University of Louisville does not have a written policy regarding secret ballots in its promotion and tenure documents.").

${ }^{188}$ See ROBERT ET AL., supra note 187, § 30, at 274 (“A member who believes that a secret vote will give a truer expression of the assembly's will can move that the vote on the motion be taken by ballot.").

${ }^{189}$ See id. $\S 45$, at 398 ("Except as may otherwise be provided by the bylaws, a vote by ballot can be ordered by a majority vote- which may be desirable in any case where it is believed that members may thereby be more likely to vote their true sentiments."). Moreover, "[w]hen the bylaws require a vote to be taken by ballot, this requirement cannot be suspended, even by a unanimous vote." Id. at 398-99. In addition, "[a] motion to make unanimous a ballot vote that was not unanimous is out of order, unless that motion is also voted on by ballot - since any member who openly votes against declaring the first vote unanimous will thereby reveal that he did not vote for the prevailing choice." Id. at 399.

${ }^{190}$ See infra note 198.
} 
As previously noted, ${ }^{191}$ I sent questionnaires to law school deans, associate deans, and professors requesting information about voting practices for hiring, retention, promotion, tenure, and dean selection. I received responses from 165 (of 168) AALS member schools (98\%) and 20 (of 22) non-member schools (91\%) - a 97\% overall response (185/190). Only five law schools - two AALS members ${ }^{192}$ and three non-members ${ }^{193}$ — did not respond to my main survey.

Significantly, $88 \%$ of U.S. law schools responding (163/185) use a secret ballot for one or more categories of personnel decisions. (The figure is $89 \%$ for AALS member schools $(147 / 165)$ and $80 \%$ for non-member schools $(16 / 20).)^{194}$ For faculty personnel decisions alone (hiring, retention, promotion, or tenure), $83 \%$ of law schools $(153 / 185)$ use a secret ballot. (The figure is $84 \%$ for member schools (138/165) and 75\% for non-member schools (15/20).) Only $7 \%$ of U.S. law schools (10/145) use a secret ballot for dean selection only and not for any other decision regarding faculty personnel. ${ }^{195}$

Separated into the various decisions on faculty personnel, the following results emerge: $76 \%$ of law schools $(141 / 185)$ use secret ballots for faculty hiring $(76 \%$ of member schools $(126 / 185)$ and $75 \%$ of non-member schools (15/20)). Of those law schools, $99 \%$ use completely secret ballots $(139 / 141-98 \%$ of member schools $(124 / 126)$ and $100 \%$ of non-member schools $(15 / 15))$. Secret ballots must be signed at $4 \%$ of law schools $(5 / 141-4 \%$ of member schools

\footnotetext{
${ }_{191}^{191}$ See supra notes 3-6 and accompanying text.

192 These schools are: University of Detroit Mercy School of Law; University of Puerto Rico School of Law; and St. Thomas University School of Law.

${ }^{193}$ These schools are: North Carolina Central University School of Law and Pontifical Catholic University of Puerto Rico School of Law.

${ }^{194}$ All percentages in this section are based on the number of schools responding in the particular category, as not all schools responded in all categories.

${ }^{195}$ All figures in this section are rounded to the nearest percent.
} 
$(5 / 126)$ and $0 \%$ of non-member schools $(0 / 15)) .{ }^{196}$ Only $1 \%$ of law schools $(2 / 141)$ require reasons along with the submission of secret ballots. (The figure is $2 \%$ for member schools $(2 / 126)$ and $0 \%$ for non-member schools (0/15).) Secret ballots for hiring decisions are automatic $^{197}$ at $94 \%$ of law schools that use secret ballots in this category $(132 / 141-93 \%$ of member schools (117/126) and 100\% of non-member schools (15/15)).

For faculty retention decisions, the figures are as follows: $67 \%$ of law schools $(105 / 157)$ use secret ballots (69\% of member schools (95/137) and 50\% of non-member schools (10/20)). Of those law schools, $98 \%$ use completely secret ballots (103/105— $98 \%$ of member schools (93/95) and $100 \%$ of non-member schools (10/10)). Secret ballots must be signed at $5 \%$ of law schools $(5 / 105-5 \%$ of member schools $(5 / 95)$ and $0 \%$ of non-member schools $(0 / 10))$. Five percent of law schools $(5 / 105)$ require reasons along with the submission of secret ballots. (The figure is $4 \%$ for member schools (4/95) and $10 \%$ for non-member schools (1/10).) Secret ballots for faculty retention decisions are automatic at $93 \%$ of law schools that use secret ballots in this category (98/105—93\% of member schools (88/95) and 100\% of non-member schools (10/10)).

The results for faculty promotion decisions are: $70 \%$ of law schools $(124 / 176)$ use secret ballots (73\% of member schools (114/156) and 50\% of non-member schools (10/20)). Of those law schools, $95 \%$ use completely secret ballots (118/124—96\% of member schools (109/114) and $90 \%$ of non-member schools $(9 / 10))$. Secret ballots must be signed at $6 \%$ of law schools (8/124-6\% of member schools (7/114) and 10\% of non-member schools (1/10)). Five percent of law schools (6/124) require reasons along with the submission of secret ballots. (The figure is $5 \%$ for member schools (6/114) and 0\% for non-member schools (0/10).) Secret ballots for

\footnotetext{
${ }^{196}$ At first glance, the figures in this sentence may appear to be at odds with those in the previous sentence. However, a school that requires that secret ballots be signed may still have a system that is completely secret if a double-blind procedure is used.

${ }^{197}$ That is, there is no necessity for a voting member to make a motion for a secret ballot.
} 
faculty promotion decisions are automatic at $92 \%$ of law schools that use secret ballots in this category (114/124-91\% of member schools (104/114) and 100\% of non-member schools $(10 / 10))$

For faculty tenure decisions, the figures are as follows: $74 \%$ of law schools $(132 / 178)$ use secret ballots (77\% of member schools $(121 / 158)$ and $55 \%$ of non-member schools $(11 / 20))$. Of those law schools, $95 \%$ use completely secret ballots $(126 / 132-95 \%$ of member schools $(115 / 121)$ and $100 \%$ of non-member schools (11/11)). Secret ballots must be signed at $7 \%$ of law schools (9/132-7\% of member schools (8/121) and $9 \%$ of non-member schools (1/11)). Five percent of law schools (7/132) require reasons along with the submission of secret ballots. (The figure is $6 \%$ for member schools $(7 / 121)$ and $0 \%$ for non-member schools (0/11).) Secret ballots for faculty tenure decisions are automatic at $92 \%$ of law schools that use secret ballots in this category (122/132 — $92 \%$ of member schools (111/121) and 100\% of non-member schools $(11 / 11))$.

The results for dean selection are: $83 \%$ of law schools (118/142) use secret ballots $(85 \%$ of member schools (106/125) and 71\% of non-member schools (12/17)). Of those law schools, $95 \%$ use completely secret ballots $(112 / 118-95 \%$ of member schools $(101 / 106)$ and $92 \%$ of non-member schools (11/12)). Secret ballots must be signed at $3 \%$ of law schools $(3 / 118-3 \%$ of member schools (3/106) and $0 \%$ of non-member schools $(0 / 12))$. Three percent of law schools (3/118) require reasons along with the submission of secret ballots. (The figure is $2 \%$ for member schools (2/106) and 8\% for non-member schools (1/12).) Secret ballots for faculty dean-selection decisions are automatic at $85 \%$ of law schools that use secret ballots in this category (100/118 - 85\% of member schools (90/106) and 83\% of non-member schools (10/12)). 
Finally, $87 \%$ of law schools (82/94) use secret ballots on other-i.e., non-facultypersonnel — decisions ( $87 \%$ of member schools $(74 / 85)$ and $89 \%$ of non-member schools $(8 / 9)) .{ }^{198}$

\section{Discussion}

Some of the results of this study stand out in a striking way. For example, most law schools in the United States use secret ballots for decisions involving faculty personnel and dean selection. The most common pattern in every category-hiring, retention, promotion, tenure, and dean selection —is that law faculties automatically use a completely secret ballot that is unsigned and that does not require a statement of reasons. ${ }^{199}$

Other results may require some explanation or further investigation. For example, respondents at some law schools wrote that they did not understand my question, "Does your faculty use secret ballots for faculty retention decisions?," or that it was not applicable at their schools. The reason is that, after an initial hire, faculty at some schools do not vote for reappointment (e.g., annually or biennially) other than when the candidate comes up for promotion or tenure. Thus, the number of schools that indicated use of secret ballots for retention (105) was significantly lower than the number that indicated use of secret ballots for hiring (141), promotion (124), or tenure (132). Nevertheless, the percentage of schools that use secret ballots for retention (67\%) is not significantly different from the percentage that use secret ballots in the other categories ( $76 \%$ for hiring, $70 \%$ for promotion, and $74 \%$ for tenure).

\footnotetext{
${ }^{198}$ These decisions include, for example: election to particular committees, such as a faculty executive committee (Illinois) or a dean's advisory committee (Nevada-Las Vegas); student petitions for readmission following academic disqualification (North Dakota, Texas Tech); recipients of certain awards (West Virginia, Southern); curriculum reform (San Francisco). More generally, many respondents added that that their schools also use secret ballots for sensitive or controversial decisions, as well as whenever a voting member of the faculty requests a secret ballot. See Appendix C. As a matter of courtesy to the requesting faculty member, faculty at some schools will accede to that request without requiring a motion or a vote (e.g., Arkansas, Colorado, Denver, Louisville, Loyola-New Orleans, Texas Tech). See id.

${ }^{199}$ See Appendix A; Appendix B.
} 
More law schools use secret ballots for dean selection (83\%) than for any other category of decisions involving faculty personnel. Yet, while the percentage is still high, use of secret ballots for dean selection is automatic less often ( $85 \%)$ than it is an all other categories ( $94 \%$ for hiring, $93 \%$ for retention, $92 \%$ for promotion, and $92 \%$ for tenure). I suspect that that the reasons are at least threefold: First, although a strong argument can be made for secret ballots in either situation, law schools are much more likely to use secret ballots automatically when the dean search involves at least one internal candidate that when all of the candidates are external. Second, law school dean search committees are typically controlled by and are largely appointed by university officials. The committees' procedures, therefore, are determined by the university administration, and not by the law school faculty. Third, dean searches occur with much less frequency than the other faculty personnel decisions discussed in this Article. From one dean search to another, therefore, procedures at a school can vary greatly.

There are some variables that I did not consider when I drafted and distributed my questionnaires. One of these is university governance structures. While at most law schools voting procedures are within the discretion of the law school faculty, at some schools universitywide rules govern. For instance, at some schools at which the law faculty uses secret ballots for hiring, they do not vote at all on promotion and tenure; that determination is made by a university committee. ${ }^{200}$

Nor did I consider the relationship between the use of secret ballots and whether a law school was public or private. It may be, for example, that—in states that have open-meetings laws - faculty at public universities are not permitted to vote by secret ballot.

\footnotetext{
${ }^{200}$ Similarly, at some law schools faculty play only a limited role in dean selection.
} 
In addition, I did not initially consider the relationship between a law school's ranking in the U.S. News \& World Report annual ranking ${ }^{201}$ and its use of secret ballots. When I tabulated the final responses in Appendix B, however, I was struck by the following discrepancy: 8 of the top 10 law schools in the U.S. generally do not use secret ballots. ${ }^{202}$ Yet the vast majority of law schools in the country—including 7 out of the next $11^{203}$ schools—generally do use secret ballots. ${ }^{204}$ Others may wish to speculate about the reasons for this apparent anomaly.

Another observation is that, although the use of secret ballots for faculty hiring is similar at AALS member (76\%) and non-member (75\%) schools, at non-member schools the use of secret ballots is far less in the other categories: retention- $69 \%$ member schools; $50 \%$ nonmember schools; promotion— $73 \%$ member schools; $50 \%$ non-member schools; tenure- $77 \%$ member schools; $55 \%$ non-member schools; dean selection—-85\% member schools; $71 \%$ nonmember schools. My sense is that the explanation has to do in large part with the newness of a school. While it is not invariably the case, many non-member law schools are relatively new and, therefore, have not gone through the necessary maturation process for enough retentions, promotions, tenures, and dean selections to have established fixed procedures.

I would be remiss if I did not point out the following limitation of this study: Many faculty—and even some members of the administration—expressed some uncertainty about their school's precise rules and practices. Thus, administrators and faculty at some schools may not agree with the descriptions of the secret-ballot procedures (or lack thereof) that one or more of

\footnotetext{
${ }^{201}$ See America's Best Graduate Schools 2007, U.S. NeWS \& WORLD REPORT, Apr. _, 2006, at 44.

${ }^{202}$ These schools are: Yale, Stanford, Columbia, Chicago, Pennsylvania, UC-Berkeley, Michigan, and Virginia. (Columbia and Pennsylvania do use secret ballots for dean selection.) The two schools that generally do use secret ballots are Harvard and NYU.

${ }^{203}$ I consider the next 11 schools, rather than 10, because there was a three-way tie for number 19.

${ }^{204}$ These schools are: Cornell, Georgetown, UCLA, USC, Vanderbilt, George Washington, and Washington University. The four schools that generally do not use secret ballots are: Duke, Northwestern, Texas, and Minnesota. (Duke does not use secret ballots for hiring, retention, or dean selection, but does use secret ballots for promotion and tenure. Minnesota does not use secret ballots for hiring or retention, but does use secret ballots for promotion, tenure, and dean selection.)
} 
their colleagues provided to me. Indeed, some faculty members had longer institutional memories than others (or than their deans). Others disagreed on nuances of their school's practices. When I encountered inconsistent or conflicting responses, I contacted the respondents for clarification. Moreover, if I received only one response from a school (typically from the dean or an associate dean), I did not write to others at the school for confirmation. ${ }^{205}$ It may be that, had I done so, I would have seen some deviations. Finally, of course, just because I may have received two (or more) consistent responses from a school does not necessarily mean that another colleague at the same school would have agreed.

Notwithstanding the foregoing explanations, anomalies, speculations, and limitationssome or all of which others may wish to pursue - the point remains that most law schools use secret ballots for most faculty personnel decisions.

\section{CONCLUSION}

The secret ballot, which originated in Australia, dates back more than 150 years. Since then, both the public and private sectors have implemented the procedure and argue that it is grounded in basic principles of democracy. Initially, the United States adopted the Australian ballot to dispel corruption within the electoral political process. Similarly, universities adopted the system as a means to enforce fairness and encourage honesty within the collegiate environment. To be sure, political elections do not provide a perfect analogy to voting in academia, because voters in political elections are permitted to use purely personal, irrational, or discriminatory bases for their votes. The intimidation factor in both contexts is palpable, however, and the secret ballot emerged as a workable solution to the problems that occurred in those contexts. Academic institutions recognized that the secret ballot system protected and

\footnotetext{
${ }^{205}$ Also, not all respondents answers all questions. In many cases, I followed up with a request for additional information. Many, but not all, respondents complied.
} 
furthered university goals while eliminating the unjustified influence of deans and higher ranking faculty members and allowing individuals to vote their conscience.

In this Article, I argue that all law schools, as highly democratic institutions, should seek to adopt a secret ballot voting system for faculty personnel decisions - those pertaining to hiring, retention, promotion, and tenure - in order to ensure candid and voluntary assessments at every level of the faculty evaluation process. Because faculty personnel decisions can be exceedingly sensitive and are among the most important questions that come before the faculty, law schools should employ secret ballot voting systems for these matters. A substantial majority— $88 \%$ - of law schools in the United States already do use secret ballots for one or more categories of faculty personnel decisions. But many law schools do not, and some that do for some purposes might consider going further.

In a perfect world, of course, we would not need secret ballots at all. Faculty would trust one another, faculty and administrators would not hunt for others' ulterior motives where none may exist, discussions would be courteous and honest, and voting would be fair and unbiased. But we do not operate in such a world. In the imperfect world in which we do operate, it may well be true that, with secret ballots, someone may vote "no" for inappropriate reasons (e.g., bias, discrimination). It is equally true, however - and perhaps even more so - that, with open ballots, someone may vote "yes" for inappropriate reasons (e.g., political correctness, sycophancy, fear of reprisals). It is critical to recognize that votes can be disguised in either type of system.

It is also critical to recognize that different law schools have different personalities, different cultures, and different climates of trust and respect. Not only do schools vary in these ways from other schools, but these factors are also dynamic and vary within schools over time- 
particularly, although not exclusively, when there is a change of administration. So the foremost criterion that faculty members should constantly address is this: which system of voting at this school at this time will lead to votes that best reflect this faculty's good faith collective judgment on the merits. At schools that cannot have a sincere and civil discussion about whether to use a secret ballot, whether generally or on a specific question, secret ballots should clearly be used.

With secret ballots — or, at the very least, with an open and honest debate about whether to conduct secret ballots - may come not only candor, but also greater harmony and collegiality. ${ }^{206}$

\section{APPENDICES}

[Note: Appendices are currently in pdf form and can be sent to you by fax email attachment, upon request. Thank you.]

\footnotetext{
${ }^{206}$ If the secret ballot is good for hiring and other faculty personnel decisions, it could also be an essential procedure for other faculty decisions - some of which can be at least as divisive. While some responses to my questionnaire addressed this matter, see supra note 198; Appendix C, and many of the arguments discussed herein would be equally applicable, that issue is beyond the direct scope of this Article.
} 